\title{
Histopathology and immunohistochemistry of peripheral T cell lymphomas: a proposal for their classification
}

\author{
T SUCHI,* K LENNERT, $\dagger$ L-Y TU, $\ddagger$ M KIKUCHI, $\uparrow$ E SATO,§ A G STANSFELD,** \\ A C FELLER† \\ From the *Department of Pathology and Clinical Laboratories, Aichi Cancer Center Hospital, Chikusa-ku, \\ Nagoya, Japan, the †Institute of Pathology, Christian-Albrecht University, Kiel, West Germany, the \\ $\ddagger$ Department of Pathology, Cancer Hospital, Shanghai First Medical College, Shanghai, China, the \\ \Department of Pathology, School of Medicine, Fukuoka University, Fukuoka, Japan, the §Department of \\ Pathology, Faculty of Medicine, Kagoshima University, Kagoshima, Japan, and the ** Department of \\ Histopathology, St Bartholomew's Hospital, London
}

SUMMARY Based on the results of histological and immunohistochemical observations of a large number of peripheral T cell lymphomas from China, England, Germany and Japan, histological and cytological morphology were correlated with immunophenotype, aetiological association with HTLV-1, and clinical behaviour to produce a working classification of the $T$ cell lymphomas.

This classification, based mainly on cytological criteria, divides the peripheral $\mathrm{T}$ cell lymphomas into tumours of low grade and high grade malignancy. Adult T cell lymphoma/leukaemia (ATLL) is caused by HTLV-1 and belongs chiefly to the high grade category. Some tumours are characterised by an admixture of other cells (epithelioid cells, follicular dendritic cells, etc) and structures (high endothelial venules, follicles), which may indicate the secretion of lymphokines by the tumour cells. Clear cells seem to be specific for $T$ cell lymphomas and may occur in various types of peripheral $\mathrm{T}$ cell lymphoma.

Since the advent of the immunological characterisation of malignant lymphomas, most nonHodgkin's lymphomas of B cell and of thymic T cell origin have been clearly defined, and the correlation between their immunological characteristics and morphological appearances well established. In contrast, lymphomas of peripheral $\mathrm{T}$ cell origin have been less well characterised.

A unique lymphoma of peripheral T cell type (adult $T$ cell leukaemia/lymphoma-ATLL) is endemic in fairly limited areas of south western Japan ${ }^{1}$ and in the Caribbean basin. ${ }^{23}$ It is caused by a type of retrovirus (HTLV-1, ATLV). ${ }^{45}$ The special features of this disease have been amply reported elsewhere. ${ }^{6-12}$ The tumour cells in ATLL and the leukaemic cells in the blood are typically pleomorphic; hence this lymphoma has been designated "malignant lymphoma of pleomorphic type" by the Lymphoma Study Group of Japan. ${ }^{13}$

On the other hand, peripheral $\mathrm{T}$ cell lymphomas that are independent of the ATL virus show extremely diverse morphological appearances, ranging from histological pictures identical with those of virus positive lymphomas to types of lymphadenopathy not hitherto regarded as malignant lymphomas. This diversity is manifest not only in the histological and clinical features but also in the immunological characteristics of the constituent cells.

There are many reports on the histological features of peripheral $\mathrm{T}$ cell lymphomas, some proposing names for more or less well defined entities: $T$ zone lymphoma ${ }^{1415}$; node-based peripheral $T$ cell lymphoma ${ }^{16} ; \mathrm{T}$ immunoblastic sarcoma ${ }^{17} ; \mathrm{T}$ cell lymphoma of large multilobated type ${ }^{18}$; $T$ cell lymphoma of large cell type ${ }^{19}$; erythrophagocytic $T$ gamma lymphoma ${ }^{20}$; and immunoblastic lymphadenopathy-like $T$ cell lymphoma. ${ }^{2122}$ Several recent reports have dealt with the subclassification of $T$ cell lymphomas. ${ }^{232426-36}$ None of the current major classifications, however, fully covers the varied spectrum of peripheral $\mathrm{T}$ cell lymphomas.

To determine whether there are clinically 
important immunological or morphological differences between virus positive and virus negative peripheral T cell lymphomas the authors held a workshop in September 1983 in Kiel to study cases from Japan, Great Britain (including cases from the Caribbean) and West Germany. ${ }^{37}$ Using both the Japanese classification ${ }^{24} 27$ and the classification proposed by Lennert et al in $1982,{ }^{31}$ we arrived at a histopathological categorisation which used the old terminology, but gave a narrower definition. This scheme was used to report the results of the workshop and proved useful in classifying peripheral $\mathrm{T}$ cell lymphomas from both Japan and Europe.

Since then the authors have attempted to create a more concrete and workable histological classification for the peripheral $\mathrm{T}$ cell lymphomas by distinguishing categories which also reflect the clinical behaviour of each entity.

An opportunity to examine and discuss a large number of $\mathrm{T}$ cell lymphomas from China was provided by the visits of one of us (L-YT) to Germany and Japan, after which KL also visited China twice. There was a further exchange of views, based on more recent findings, at the third German-Japanese conference on lymphoid malignancies in 1986. At the same time, the European Lymphoma Club met several times to discuss updating the Kiel classification, with special reference to the peripheral $\mathrm{T}$ cell lymphomas.

Despite these repeated meetings and exchanges of views the task of agreeing on a workable classification for peripheral $T$ cell lymphomas was formidable. The greatest obstacles were encountered in classifying the high grade tumours, and it was almost impossible to achieve a subdivision of these which was reproducible, even between experts, and which, at the same time, corresponded with both the characteristics of the constituent cells and with the clinical behaviour of the tumours. Undoubtedly, this was because peripheral $\mathrm{T}$ cell lymphomas exhibit a continuous spectrum of extremely diverse histological pictures, even within what seem to be single types of tumour.

The clinical behaviour of peripheral $\mathrm{T}$ cell lymphomas is also unpredictable; a patient with a low grade tumour may die very soon, or a low grade tumour may progress rapidly into a high grade tumour, and tumours are occasionally observed to regress spontaneously.

The authors eventually concluded that most of the high grade $\mathrm{T}$ cell lymphomas should, for the present, be lumped into a comprehensive category, diverse as the histological features of this category might be.

In this paper we propose a histopathological classification of the $T$ cell lymphomas (table 1); we also provide detailed histological descriptions of the major subtypes of peripheral $\mathrm{T}$ cell lymphomas, based on Giemsa and haematoxylin and eosin stained
Table 1 T cell lymphoma/leukaemia

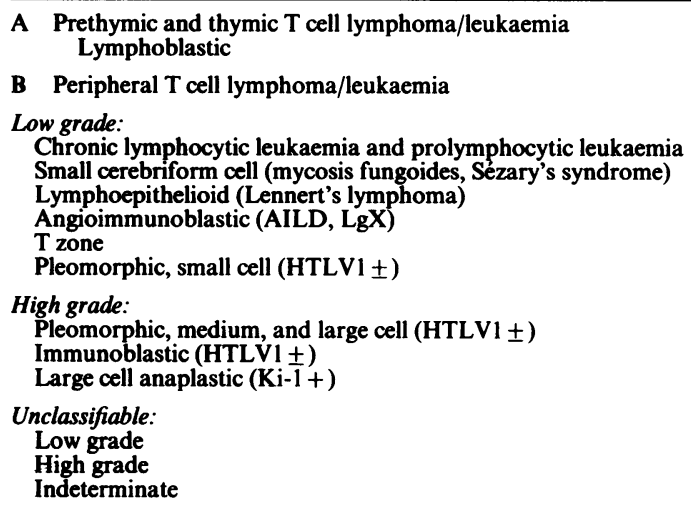

sections, and their correlation with immunological and some clinical data. Thymic and prethymic malignant lymphomas have already been well documented. ${ }^{38-40}$

\section{Lymphomas of low grade malignancy}

(i) CHRONIC LYMPHOCYTIC LEUKAEMIA AND PROL YMPHOCYTIC LEUKAEMIA (fig 1)

Most, if not all, cases of small lymphocytic type seen in histological section are accompanied by a leukaemic or subleukaemic picture, and can be interpreted as cases of chronic lymphocytic leukaemia of $T$ cell type (T-CLL), or $\mathrm{T}$ prolymphocytic leukaemia (T-PLL).

The $\mathrm{T}$ cell leukaemias can be subdivided according to the cytological and immunological features of the leukaemic cells into the following four subtypes, as recommended by Lennert et al ${ }^{31}$ : "knobby" type; azurophilic type; pleomorphic type; and prolymphocytic leukaemia. The pleomorphic type of T-CLL is invariably HTLV-1 negative and is therefore unrelated to the leukaemic phase of ATLL (pleomorphic lymphoma of Japan).

The first subtype is characterised by irregular protrusions of the nuclei, hence the colloquial designation "knobby" (Lukes RJ, personal communication). The cell size is roughly equivalent with that of peripheral blood lymphocytes or a little larger.

The second subtype is characterised by roundish regular nuclei and azurophilic granules in the cytoplasm. These cells are also found in normal peripheral blood and comprise about $5 \%$ of blood T lymphocytes.

The third subtype ${ }^{41}$ exhibits very irregular nuclei with deep invaginations and has some morphological 


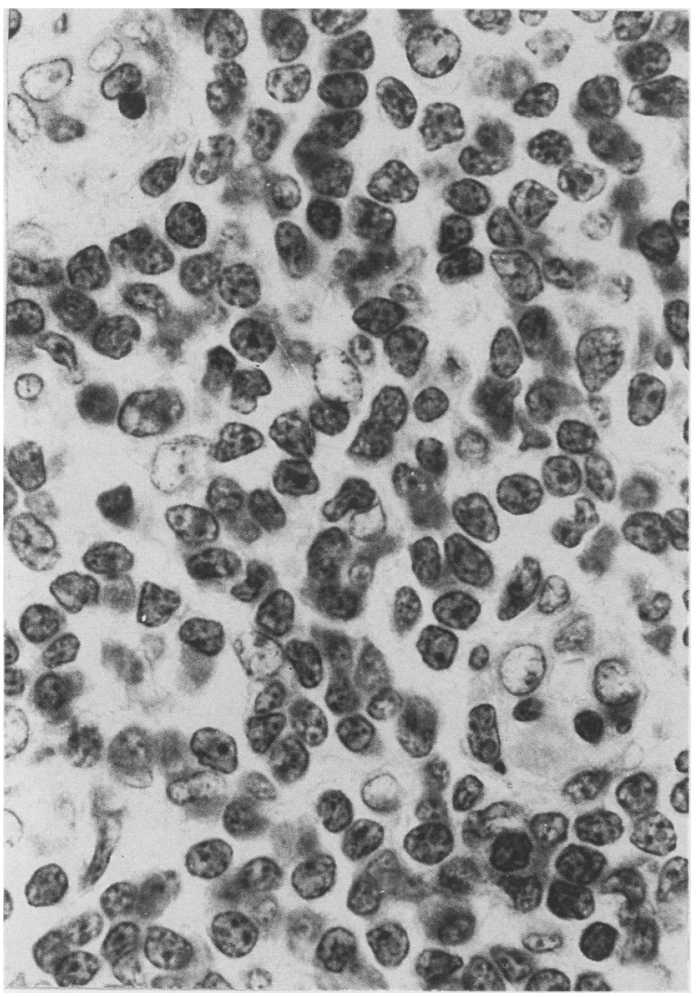

Fig 1 Chronic lymphocytic leukaemia of $T$ type (T-CLL) "knobby" type containing small lymphocytes with slightly irregular nuclei. Two atypical high endothelial venules are also visible. (Haematoxylin and eosin.)

similarities to ATLL, ${ }^{42}$ which has an even greater nuclear irregularity. The pleomorphic type occurs predominantly in younger patients and has a poor prognosis.

In the fourth subtype ( $T$ prolymphocytic leukaemia) the leukaemic cells are somewhat larger than blood lymphocytes and have a single prominent nucleolus. The nuclei may be round or irregular. The round cell variant has a more abundant cytoplasm. Irrespective of their nuclear configuration, both types have a distinctly basophilic cytoplasm in clear contrast to T-CLL. Although a number of cases of TCLL have recently been classified as T-PLL by Matutes et $\mathrm{l}_{,}{ }^{43}$ we think that it is only possible to diagnose T-PLL if the following criteria are met: (i) the cells are larger than cells of T-CLL and blood T lymphocytes; (ii) they have a single prominent large nucleolus; (iii) a broad rim of clearly basophilic cytoplasm. ${ }^{445}$ The clinical features do not allow for a clear distinction to be made, except in leukaemias of azurophilic type. All other types often have high white cell counts, splenomegaly, or skin infiltrates.
The histological picture of T-CLL shows a monotonous sheet made up of small lymphocytes with round or irregular nuclei, interspersed with a few large basophilic blast cells, which usually show several medium sized basophilic nucleoli. Unlike BCLL, there are no proliferation centres, but a large number of high endothelial venules. Small areas of intact $B$ cell aggregations and even unaffected $T$ areas may be discernible; they appear as accumulations of small lymphocytes.

In contrast to the "knobby" subtype, the azurophilic and the pleomorphic subtypes are not regularly accompanied by spread to the lymph nodes. The same is true for T-PLL. Immunologically, the leukaemic cells of the "knobby" type are of helper/inducer phenotype (CD3 positive, CD4 positive, CD8 negative), whereas the azurophilic type shows a suppressor/cytotoxic phenotype (CD3 positive, CD4 negative, CD8 positive, with inconstant expression of Leu 7). The pleomorphic subtype expresses CD3 and CD8 but is constantly CD4 negative, in contrast to the Japanese ATLL, which is CD4 positive but CD8 negative.

T-PLL may express CD4 or CD8 antigen-in rare cases simultaneously. ${ }^{46}$ Furthermore, there is always expression of CD7 which is also found in T lymphoblastic lymphomas/leukaemias but inconstantly in TCLL. ${ }^{40}$ There may also be transformation (as in B cell types) from T-CLL to T-PLL, with individual cases partly showing the features of both $T$ cell neoplasms, which makes it difficult to make a clear cut distinction between CLL and PLL.

The prognosis is best in the azurophilic subtype. The T4 positive "knobby" type has an intermediate prognosis, whereas T8 positive pleomorphic type (without azurophilic granules) and prolymphocytic leukaemia have a rather poor prognosis.

(ii) SMALL CEREBRIFORM CELL (MYCOSIS FUNGOIDES AND SÉZARY'S SYNDROME) (fig 2)

Two clinically distinct $T$ cell lymphomas which initially manifest in skin, mycosis fungoides and Sézary's syndrome, ${ }^{4748}$ can also be recognised morphologically in their early phase by the presence of small $T$ lymphocytes with extreme nuclear convolutions ("cerebriform" or "Lutzner cells"). ${ }^{49}$ The nuclear configuration of these cells can be better appreciated in electronmicroscopic preparations, as shown by many authors. ${ }^{5051}$ These cells are intermingled with larger atypical cells, especially in cases of mycosis fungoides, and usually show epidermotropism, often with Pautrier's pseudoabscesses. In later stages increasing anaplasia of the cells may result in transformation into a high grade lymphoma of pleomorphic (medium sized or large cell), immunoblastic, or large cell anaplastic type. 


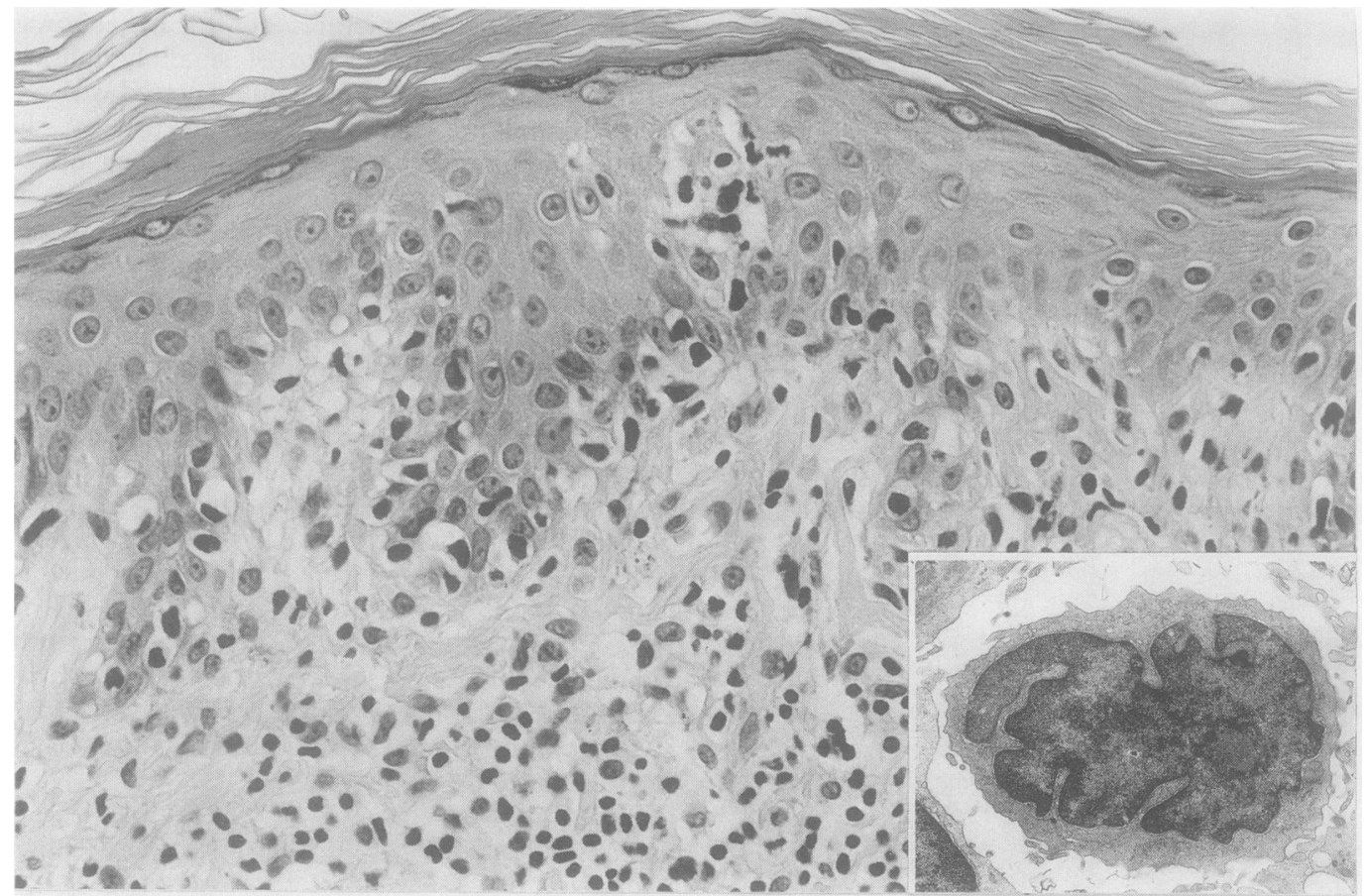

Fig 2 Small cerebriform type (mycosis fungoides). Mostly small and some larger lymphocytes with pronounced nuclear irregularity are seen infiltrating into the upper dermis as well as into epidermis giving it a moth-eaten appearance. Nuclear irregularity is better appreciated in an electron micrographic picture (insert). (Haematoxylin and eosin.)

\section{(iii) LYMPHOEPITHELIOID (LENNERT'S}

LYM P HOMA) (figs 3 and 4)

Lymphoepithelioid lymphoma (LeL) was described by Lennert ${ }^{5253}$ as a special variant of Hodgkin's disease ("epitheloidzellige Lymphogranulomatose"). In 1957 the name lymphoepithelioid cell lymphoma (LeL) was proposed, based on the assumption that this was a specific non-Hodgkin's lymphoma. ${ }^{54}$ The predominance of $T$ cells ${ }^{1755-58}$ could not be accepted as final evidence for interpreting LeL as a $T$ cell lymphoma, as $\mathrm{T}$ cells usually predominate in Hodgkin's lymphoma as well. The combination of reactivity with $\mathrm{T}$ cell markers and an associated proliferation antigen (Ki67), however, ${ }^{59-61}$ provided strong evidence for LeL being a malignant lymphoma of CD4 cells (helper/inducer T cells). This was further substantiated by cytogenetic ${ }^{62}$ and DNA rearrangement studies. ${ }^{6163}$

LeL was given the eponymous title "Lennert's lymphoma" by Dorfman and Warnke, ${ }^{64}$ Lukes and Tindle, ${ }^{65}$ and others. Unfortunately, other lesions with a histological resemblance to LeL have been included under this title, which led Kim et al ${ }^{66}$ to reject LeL as an entity. This is unjustified, but it emphasises the importance of adhering rigidly to the essential diagnostic criteria and to the use of immunohistochemistry to exclude B cell lymphomas of similar morphology, especially lymphoplasmacytoid (LP) immunocytoma.

According to the original description of $\mathrm{LeL}$, the main cell type is a small lymphocyte and contains a round or slightly irregular nucleus with a coarse chromatin. The irregularity of the nuclei becomes more prominent in technically bad paraffin sections, but if the same block is re-embedded into plastic, the nuclear irregularity is usually minimised. The cytoplasm is most scanty and grey (in Giemsa staining). A few cases show a more abundant, water-clear cytoplasm ("clear cells"), ${ }^{67}$ but the cytoplasm is not as abundant as in the clear cells of other $T$ cell lymphomas (AILD-type or T zone lymphoma).

Some medium sized and large cells are also always found. The medium sized cells show round nuclei with a fine chromatin and small nucleoli. The cytoplasm is rather sparse and only slightly basophilic. The large cells have the classic appearance of immunoblasts and cannot be distinguished from B immunoblasts by morphology alone. They contain a round to oval nucleus with one large centrally located basophilic nucleolus (dark blue in Giemsa staining), and sometimes one to two additional small to medium sized nucleoli. 
The most prominent feature of the lesion is the presence of small clusters of large epithelioid cells; there may also be single epithelioid cells or even large sheets of epithelioid cells. The nuclei of the epithelioid cells are oval or reniform and often larger than those seen in non-neoplastic lesions such as sarcoidosis. They contain relatively large, solitary, non-basophilic nucleoli (violet in Giemsa staining). The cytoplasm is abundant and oxyphilic, with a rounded paranuclear area which is strongly positive on periodic acid Schiff staining (Golgi body?). Sometimes multinucleated epithelioid cells (Langhans' giant cells) occur.

Finally, some eosinophils and polytypic plasma cells are usually found. Sternberg-Reed cells or Hodgkin's cells are not seen, or at most only a very small number per section. More than two Sternberg-Reed cells in a section favour a diagnosis of Hodgkin's disease of mixed type with a high content of epithelioid cells.

Mitoses are usually rare and occur only in T cells, not in epithelioid cells, and this can be shown by the

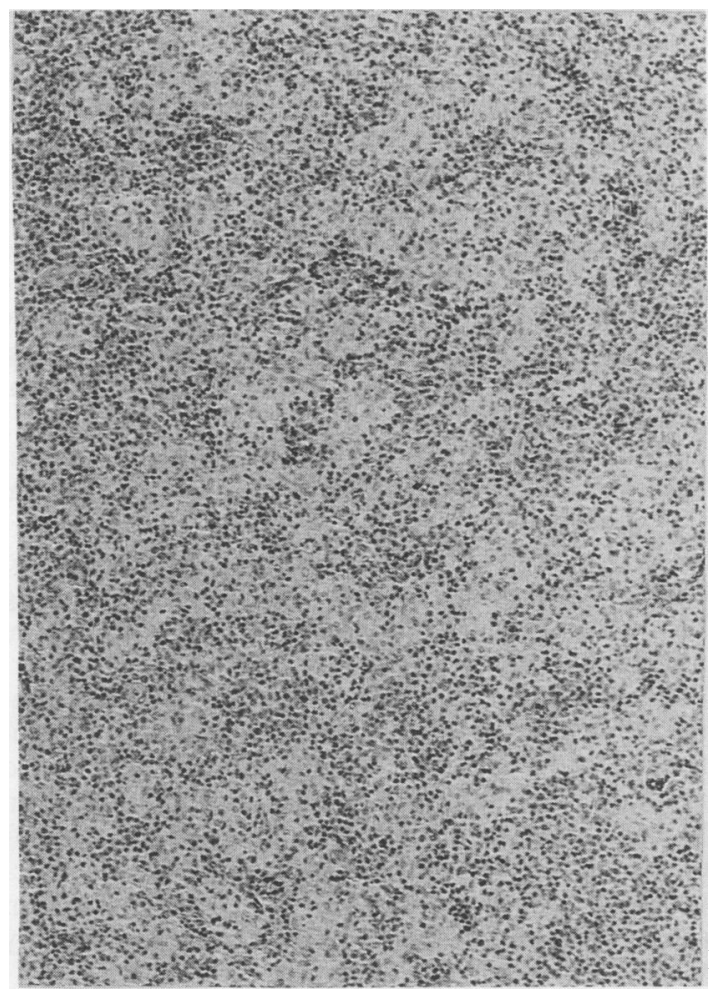

Fig 3 Lymphoepithelioid (Lennert's) lymphoma. Numerous clusters of epithelioid cells are scattered throughout the field; intervening neoplastic and some reactive lymphoid cells. (Haematoxylin and eosin.) combined use of $\mathrm{Ki67}$ antibody with $\mathrm{T}$ cell and histiocytic markers for immunostaining.

Follicles, especially those with germinal centres, are absent or occur only as isolated remnants. Reticulin fibres are found in small to moderate numbers; a conspicuous fibrosis of the tumour is not seen. Necrosis does not occur in LeL. High endothelial venules are usually found only in small numbers.

Medium sized and large T cells are most often seen in and around the clusters of epithelioid cells. Thus the activated $T$ cells may produce lymphokines which attract monocytes to be transformed into epithelioid cells. The unusually large size of the epithelioid cells could be due to a lack of immunoregulation such as functions in sarcoidosis and other epithelioid cell reactions, and the large size of these cells in LeL should not be taken as an indication of their malignancy.

This type of peripheral T cell lymphoma more often presents with localised lymphadenopathy (especially in the neck) than other tvpes. Hepatosplenomegaly is

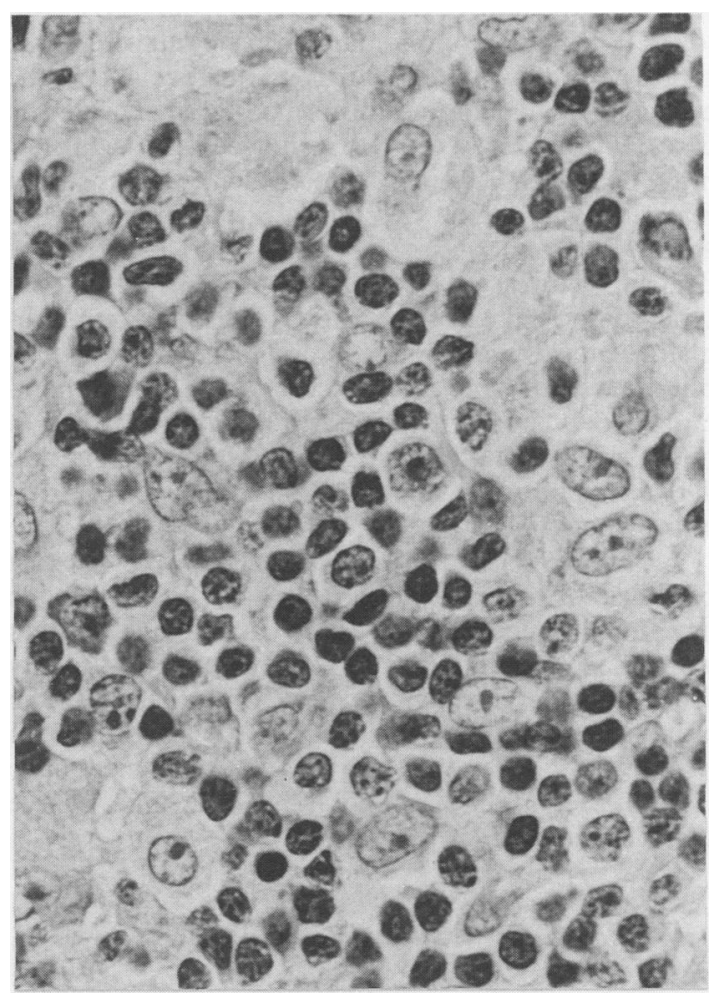

Fig 4 Lymphoepithelioid (Lennert's) lymphoma. The nuclei of the proliferating lymphoid cells are predominantly round, but a few of the nuclei show characteristic indentations. A few blastic cells and a mononuclear Hodgkin-like cell are seen. Some nuclei of the epithelioid cells are larger than those seen in reactive lesions. Clear cells are occasionally seen.

(Haematoxylin and eosin.) 
rare, but spread to the tonsils is rather common. Constitutional symptoms are mild and a skin rash is usually absent. Serum immunoglobulin concentrations are either normal or slightly raised. LeL is never HTLV-1 positive. Cases of LeL were studied by Patsouris using the abundant material on file in the lymph node registry in Kiel (unpublished observations). The main purpose of his study was to search for morphological and immunohistochemical criteria to distinguish true LeL from similar lesions rich in epithelioid cells. In a total of 367 cases rich in epithelioid cells and suspected of being LeL, Patsouris found only $30.0 \%$ which were typical LeL. In $30.3 \%$ Hodgkin's lymphoma was diagnosed $(27.0 \%$ mixed cellularity and $3.3 \%$ lymphocytic predominant type), in $26.4 \%$ a special variant of $L e L$ with features of angioimmunoblastic lymphadenopathy with dysproteinaemia (AILD), and in $10.7 \%$ LPimmunocytoma. Finally, $1.5 \%$ were miscellaneous B and $\mathrm{T}$ cell lymphomas and $1 \cdot 1 \%$ inflammatory lesions (miliary tuberculosis, Whipple's disease etc).

Briefly, the non-LeL cases differed from LeL as follows: Hodgkin's lymphomas always contained some typical Hodgkin's and Sternberg-Reed cells and the epithelioid cells commonly formed large sheets. The cases with features of AILD showed an increase of high endothelial venules, often with fibrosis and hyalinisation of the vessel walls. The number of eosinophils and plasma cells was also higher. The clinical features were similar to those of the AILD type described in the next section. Immunohistochemically, the admixture of CD8 positive lymphocytes was more pronounced than in LeL, and large sheets of follicular dendritic cells were found in the cases that could be investigated in fresh material. This lymphoma was therefore considered to be a variant of the AILD type.

LP-immunocytoma can be recognised by the presence of plasmacytoid cells with a monotypic immunoglobulin pattern. These cases are sometimes associated with Sjögren's syndrome and are mainly found in older women, whereas the other LeL-like lesions, including LeL itself, show a clear cut peak in the seventh decade. More men than women have Hodgkin's lymphomas and the AILD type, where LeL affects both sexes equally.

\section{(iv) ANGIOIMMUNOBLASTIC (AILD: LgX) TYPE} (figs 5 and 6)

The lesions with the histological features of this type were originally regarded as an abnormal immune reaction and were presented as a non-neoplastic condition of uncertain nature by different authors, more or less simultaneously, using different terms: lymphogranulomatosis X (LgX), ${ }^{68}$ immunodysplastic disease
Suchi, Lennert, Tu, Kikuchi, Sato, Stansfeld, Feller (IDD), ${ }^{67}$ angioimmunoblastic lymphadenopathy with dysproteinaemia (AILD), ${ }^{69}$ immunoblastic lymphadenopathy (IBL). ${ }^{65}$

Lukes and Tindle ${ }^{65}$ reported that some of their cases of IBL had developed immunoblastic sarcomas either in the biopsied specimens or at necropsy. Nathwani et al $^{70}$ asserted that areas of immunoblastic sarcoma could be found as aggregates of large cells in the lesions of AILD. Such cases showed a shorter survival time. Although the authors of both papers could not specify the immunological character of the "immunoblastic sarcomas", they may have been predominantly of B cell lineage. ${ }^{71}$

Shimoyama et $a l^{21}$ and Watanabe et $a l^{22}$ postulated that the lesions described as AILD are actually a type of peripheral $\mathrm{T}$ cell lymphoma, and they advocated the term "IBL-like T cell lymphoma". They further asserted that this type is of suppressor/cytotoxic phenotype, in contrast to the helper/inducer phenotype of most other $T$ cell lymphomas.

Since then, evidence has gradually accumulated, first by the demonstration of non-random (clonal) abnormalities of chromosomes ${ }^{72-74}$ and more recently by the detection of clonal rearrangement of the $\beta$ - and $\gamma$-chains of $T$ cell antigen receptor and immunoglobulin genes, ${ }^{75-77}$ which indicate strongly that this lesion is not merely an abnormal immune reaction but indeed - at least in a high proportion clonal $\mathrm{T}$ cell proliferation and thus may be interprete as a $\mathrm{T}$ cell lymphoma. The remaining cases, where clear cut evidence of neoplasia is lacking, may be interpreted as prelymphomatous or dysplastic lesions, or even as truly reactive conditions ("abnormal immune reactions").

In this type of $\mathrm{T}$ cell lymphoma follicles are indistinct or absent and germinal centres are seldom found. Only in very early infiltrations may single germinal centres be seen. About half of the cases show so called "burned-out" germinal centres, ${ }^{6978}$ consisting only of dendritic reticulum cells, but it is evident from immunohistochemical studies (unpublished observations) that the dendritic cells are actually not remnants but proliferating cells which form large irregular sheets of dendritic reticulum cells which also infiltrate the $\mathrm{T}$ area. The proliferation can be shown by combining the Ki67 antibody (detecting a proliferation antigen) and Ki-M4 (detecting dendritic reticulum cells). This proliferation of dendritic reticulum cells may be stimulated by lymphokines produced by the tumour cells.

There is always a remarkably large number of high endothelial venules in which the endothelial nuclei are sometimes plump, sometimes more flat. These vessels often show an arborising pattern and thickened basement membranes containing material positive for periodic acid Schiff. The same hyaline material is . 要

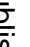

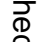

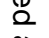
年 定 i.

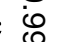
: 年

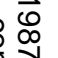
음

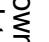
을 임 


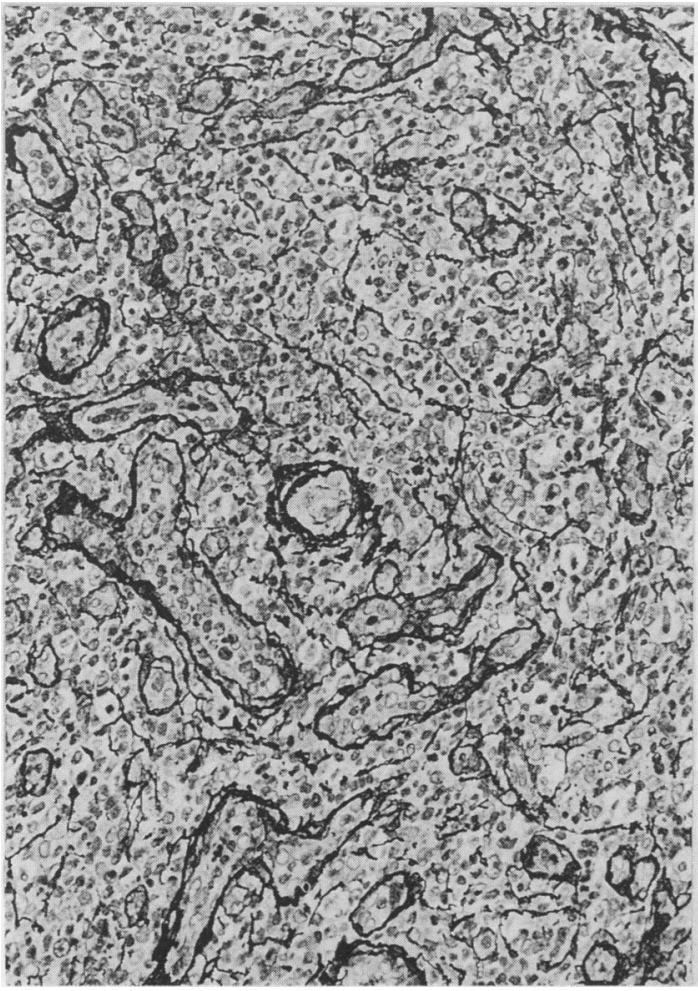

Fig 5 Angioimmunoblastic (AILD) type. The characteristic finding of many arborising venules with plump endothelial nuclei (high-endothelial venules, $\mathrm{HEV}$ ) is readily shown by a reticulin stain. (Gomori's silver impregnation.)

found in the adventitia of small and medium sized arteries. $^{79}$

The tumour cells are mainly small to intermediate and have irregular nuclei with small nucleoli and lightly stained cytoplasm. Intermingled large lymphoid cells with moderately atypical nuclei and some typical T immunoblasts are often found. Clusters of large "clear cells" are commonly seen. 677179 There are also aggregates of plasma cells and their precursors (plasmablasts, immunoblasts), sometimes in large numbers. Epithelioid cell clusters are quite pronounced in some cases and these cases have been often misinterpreted as examples of LeL. Immunologically we can show that such cases have the typical network of dendritic reticulum cells that is peculiar to the AILD type.

The lymphomas of this type are usually HTLV-1 negative. In contrast to the findings of Shimoyama $e t$ $a l^{21}$ and Watanabe et $a l,{ }^{22}$ Lennert et $a l^{80}$ and Namikawa et $a l^{81}$ found that the proliferating cells (Ki67

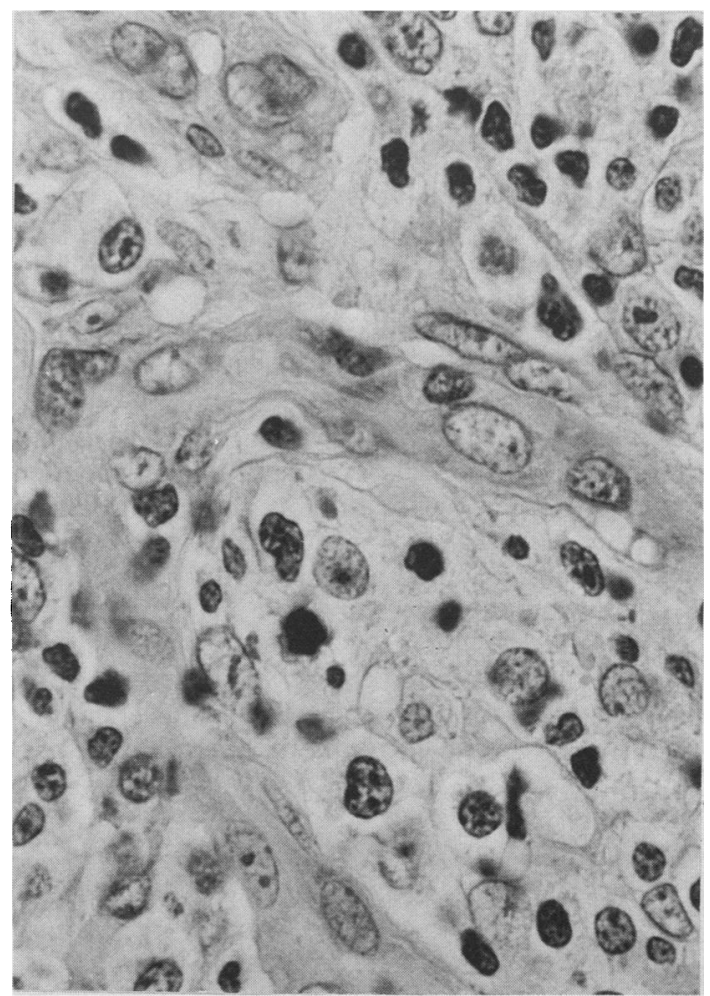

Fig 6 AILD type. Clusters of clear cells are seen around the arborising venules. Most of the clear cells show round nuclei of small to large size, but many of the nuclei, especially of non-clear cells, are moderately pleomorphic (right of the field). (Haematoxylin and eosin.)

positive, Pola positive) were predominantly of helper $T$ cell phenotype; but there was always an admixture of at least some suppressor $\mathrm{T}$ cells which were also proliferating. In exceptional cases suppressor cells were the predominant proliferating cell type. The question as to whether tumours consisting exclusively of suppressor cells exist still remains open.

DNA arrangement studies by Griesser $e t a^{82}$ have shown that tumours of this type differ from other types of $T$ cell lymphoma in that they show rearrangement of immunoglobulin heavy chain gene (JH) in a large number of cases in addition to the rearrangement of T cell receptor $\gamma$ and $\beta$ chain genes.

Cases of the AILD type often have an acute or subacute onset with severe constitutional symptoms. Skin rashes due to drug hypersensitivity and frank hyperglobulinaemia associated with various autoimmune phenomena are well known findings in this type of lymphoma, as originally described in AILD ${ }^{83}$ or lymphogranulomatosis $\mathrm{X}^{84-86}$ 


\section{(v) T ZONE LYMPHOMA (figs 7 and 8)}

The term $\mathrm{T}$ zone lymphoma was originally given to a tumour growing in the $\mathrm{T}$ zones and consisting of the normal constituents of the $T$ zones ( $T$ lymphocytes, interdigitating reticulum cells, epithelioid venules). ${ }^{5487}$ The B areas (follicles) were found to be preserved or even hyperplastic in the early stage of the tumour infiltration. Later on, however, the follicles disappear and a diffuse pattern develops. Consequently, we distinguish two phases of $\mathrm{T}$ zone lymphoma, one with prominent follicles and one without follicles.

The cytology of $\mathrm{T}$ zone lymphoma is also somewhat variable. The cells are mainly small to intermediate lymphoid cells, without pronounced pleomorphism, and have a scanty grey cytoplasm on Giemsa staining. Sometimes clusters or sheets of these cells show abundant water clear cytoplasm (clear cells). Interspersed there are large basophilic blasts in small or moderate numbers in which the degree of basophilia may be low or high. Their nuclei contain one large or several medium sized violet (Giemsa)

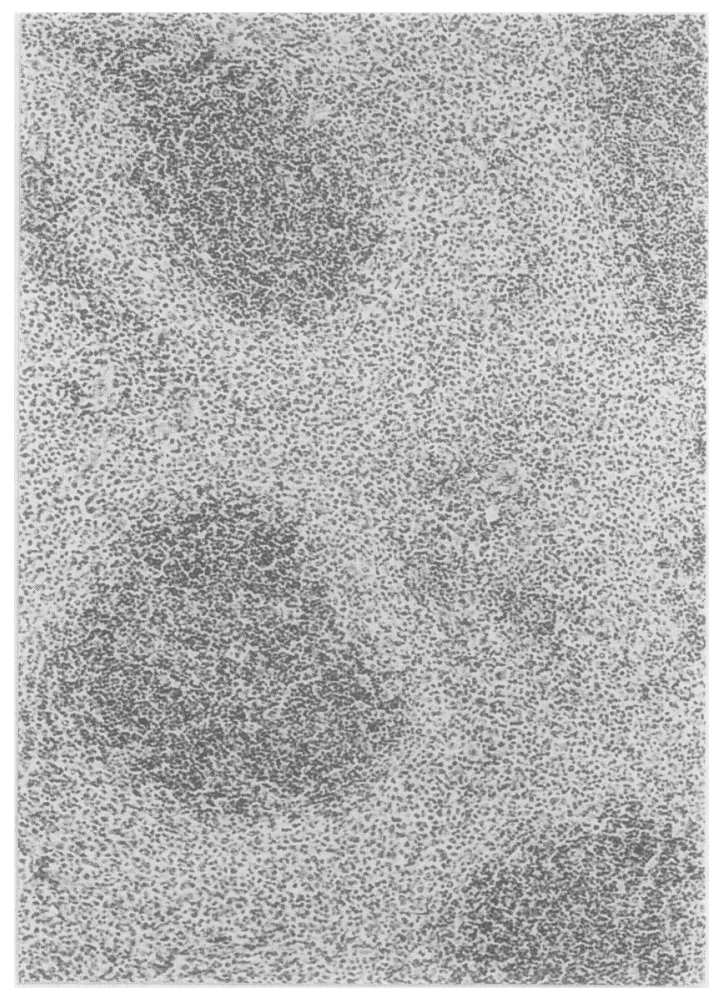

Fig 7 T zone lymphoma with follicles. The neoplastic cells are diffusely infiltrating into the interfollicular areas, preserving large distinct follicles (without germinal centres in this case). (Haematoxylin and eosin.)
Suchi, Lennert, Tu, Kikuchi, Sato, Stansfeld, Feller

nucleoli. Cells resembling mononuclear Hodgkin's cells or even Sternberg-Reed cells may also be seen occasionally.

The T cell nature of this type of lymphoma is usually evident from distinct histological landmarks, such as the distribution of neoplastic cells within the $T$ zones (with or without preservation of follicles) and the presence of conspicuous high endothelial venules. ${ }^{88}$ An admixture of various reactive cellsnotably, epithelioid cell clusters ("Lennert's lesion")-eosinophils and plasma cells, is also notable. Occasionally nests of so called plasmacytoid $T$ cells are found. 8991

Lymphomas of $\mathrm{T}$ zone type are occasionally seen in which prominent, hyperplastic germinal follicles are accompanied by modest expansion of the $T$ zones by an infiltrate showing only mild atypia. ${ }^{77}$ These may be misdiagnosed as reactive follicular hyperplasia or even follicular lymphoma. T zone lymphomas without follicles, and sometimes with many clear cells, are often seen in China, where they are referred to as the "diffuse, mixed type of $T$ cell lymphoma". T zone lymphoma has sometimes been observed to progress to become a high grade $T$ cell lymphoma.

T zone lymphoma is usually HTLV-1 negative. Immunohistochemically, it contains a considerable number of non-neoplastic B cells, often in aggre 8 gations, even in cases which are histologically "with out follicles". Moreover, large numbers of T cells ofe both helper and suppressor subsets are often found, but it has been shown by Lennert et $a l^{80}$ that the proliferating cells (Ki67 positive cells) of the lesions are of the CD4 positive helper type in all cases.

Lymphomas of $\mathrm{T}$ zone type often begin with symptoms of malaise, fever, and sometimes skin rashes. Lung or pleura are often affected $(45 \%) .{ }^{92}$ The serum immunoglobulin concentration often shows mild to moderate polyclonal increase. Leukaemia is rare.

(vi) PLEOMORPHIC, SMALL CELL TYPE (fig 9)

The lymphomas of pleomorphic type are diffuse tumours composed of neoplastic cells, in which the irregular configurations of the nuclei give a hint of their $\mathrm{T}$ cell nature. Among the lymphomas with this feature, those composed predominantly of small to intermediate sized cells are included in the pleomorphic small cell type because these generally have a much better prognosis than the cases of pleomorphic type with medium sized to large cells.

In contrast to the constituent cells of the $T$ zone lymphoma, which show a fair number of larger cells including $\mathrm{T}$ immunoblasts, the neoplastic cells of the pleomorphic small cell type vary only slightly in size but considerably in shape. The proliferating cells appear rather monotonous, often sparing seemingly inactive follicles of smaller B lymphocytes. The nuclei 


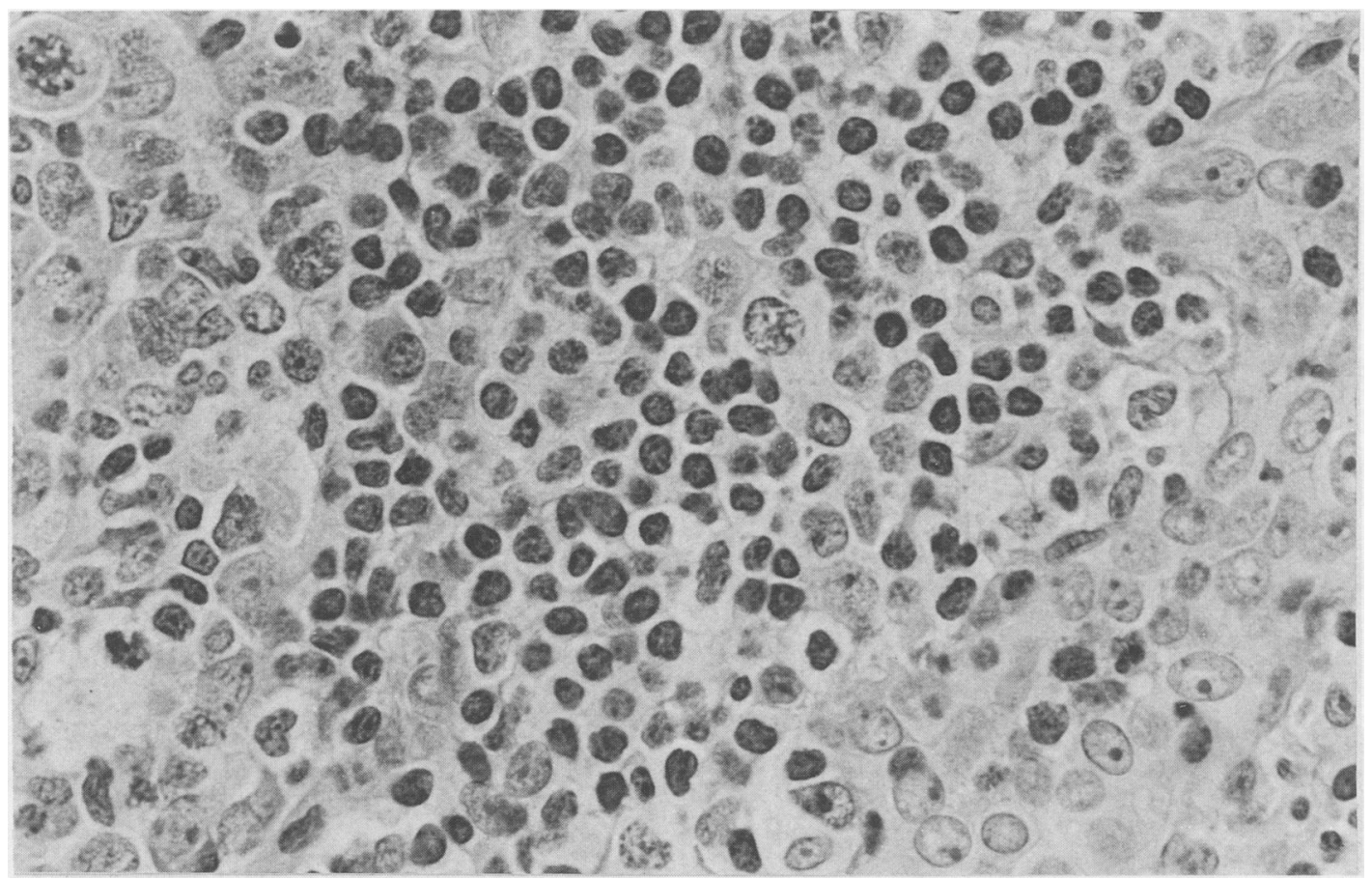

Fig $8 T$ zone lymphoma, with follicles. Neoplastic cells in the $T$ zone in another case are predominantly small, but some larger cells including $T$ immunoblasts are intermingled. Many of their nuclei, especially larger ones, are either indented or irregularly shaped. Clear cells are scattered. A large clear cell with "jelly fish" nucleus is seen on the right. A "naked" germinal centre is seen on the left, and a high endothelial venule on the right. (Haematoxylin and eosin.)

are moderately to severely irregular, and mitotic figures are rare. The cytoplasm is usually scanty and weakly stained, but occasionally clear cells aggregate in sheets. The neoplastic cells of this type are usually of helper/inducer phenotype (CD3 positive, CD4 positive, CD1 negative, CD8 negative).

Clinically, there are HTLV-1 positive and negative cases. The negative cases fairly often affect the skin and are sometimes simultaneously found with lymph node enlargement at the onset of the disease. Leukaemia is unusual.

The cases of the so called chronic ATLL (HTLV-1 positive) usually show this type of picture. In this instance the irregularity of the nuclei is particularly pronounced, but giant cerebriform nuclei, a marker cell of viral aetiology are only rarely seen. The chronic variant of ATLL usually has mild symptoms, with fewer leukaemic cells and without hypercalcaemia, but skin disease is common. It is worth while distinguishing chronic ATLL from those HTLV-1 positive cases, in which the lymphoma is initially of pleomorphic small cell type, but in which rapid transformation to a large cell type or the presence of hypercalcaemia confer a much worse prognosis. ${ }^{2} 3$

\section{Lymphomas of high grade malignancy}

(i) PLEOMORPHIC, MEDIUM SIZED, AND LARGE CELL VARIANTS (figs 10-12)

The pleomorphic lymphomas described in this section are also diffuse tumours, composed of variable sized neoplastic cells with very atypical nuclear configurations, variously described as convoluted, hyperconvoluted, cerebriform or multilobulated. They may be subdivided into two variants, based on the size of the nuclei of the predominant cells: a medium sized cell variant; and a large cell variant.

The tumours associated with HTLV-1 infection (adult T cell lymphoma/leukaemia or ATLL) mostly belong to this category, but not all pleomorphic $T$ cell lymphomas are HTLV-1 positive. Conversely, virus positive tumours sometimes show the morphological features of the immunoblastic or the pleomorphic small cell types. Three of the present authors (TS, MK, and ES) have rarely found adult $T$ lymphoma/leukaemia antigen (ATLA) positive cases with the features of Lennert's lymphoma, the AILD type, and tumours entirely composed of clear cells. Furthermore, one of the Japanese ATLA positive cases from the series of Lennert et $a l^{37}$ showed the 


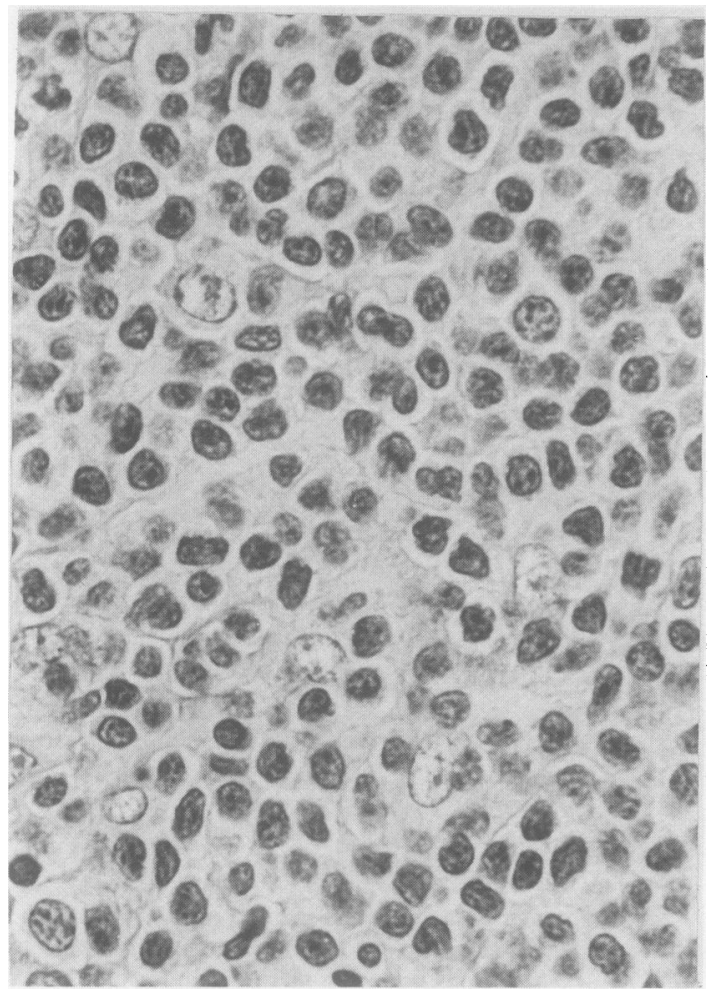

Fig 9 Pleomorphic small cell type. A diffuse tumour predominantly composed of small to intermediate sized cells with characteristic nuclear configuration of $T$ cells is seen. A few blasts are seen, but the proliferating cells are otherwise fairly uniform. This case was HTLV-negative and of a helper $T$ cell type. (Haematoxylin and eosin.)

typical histological features and immunophenotype of a large anaplastic cell (Ki-1 positive) lymphoma. In this classification it is recommended that cases of ATLL be specifically designated as such, together with the diagnosis of the histological type.

As most cases of ATLL correspond to the pleomorphic sized or large cell type, the specific features of this disease are now described, and the ways in which HTLV-1 negative cases differ are indicated. The pres-. ence of an antibody in the patient's serum to a virus associated antigen (ATLA) provides a practical and useful diagnostic test for the virus positivity of a tumour or leukaemia.

\section{Adult T cell leukaemia/lymphoma (ATLL) 6825}

The peculiar form of peripheral $T$ cell neoplasia caused by a type of retrovirus HTLV $-1^{493}$ was first found by Takatsuki et $a l^{1}$ to be endemic in certain areas of south western Japan, notably Kyushu, the
Suchi, Lennert, Tu, Kikuchi, Sato, Stansfeld, Feller

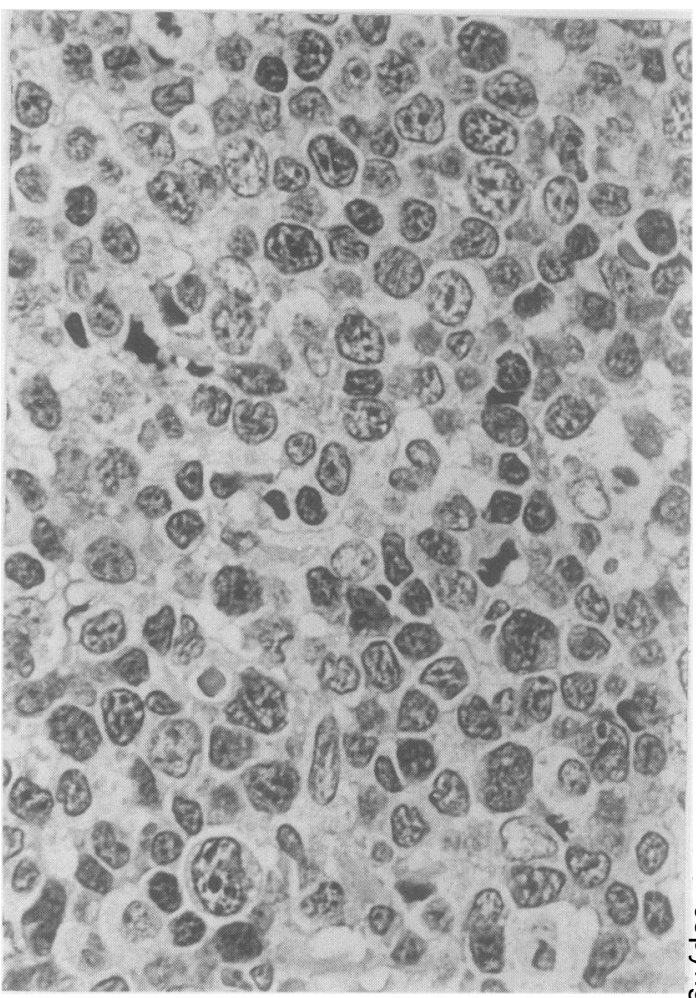

Fig 10 Pleomorphic medium sized cell type (adult $T$ cell leukaemia/lymphoma). The nuclei of neoplastic cells are predominantly medium sized, and many of them show deep complex invaginations. Some nuclei show a stippled chromatin pattern. Most of the tumour cells were of a helper (CD4 positive) phenotype, but many of the cells reacted with both CD4 and CD8. (Haematoxylin and eosin.)

most south western of the four main islands. ${ }^{7}$ The same disease is also known to cluster in the Caribbean basin and in the migrant population from this region in the United Kingdom. ${ }^{2}$ Cases have been observed in the United States of America. ${ }^{94} 10$

The disease is usually leukaemic or subleukaemic, but a lymphoma type without leukaemia also occurs. It is essentially a disease of adults, with a mean age of 57 years and a male:female ratio of $1 \cdot 4: 1$, affecting fewer men than most other types of lymphoma in Japan. ${ }^{95}$

The morphology of the leukaemic cells in the peripheral blood is characteristic in that their nuclei show strong lobulation ${ }^{42}$ and have been called "flower cells". Immunologically they are of helper/inducer phenotype ${ }^{96}$ but have suppressor function on $B$ cell differentiation in vitro. ${ }^{25}$

Because bone marrow disease is usually mild, patients do not have clinically important anaemia. 


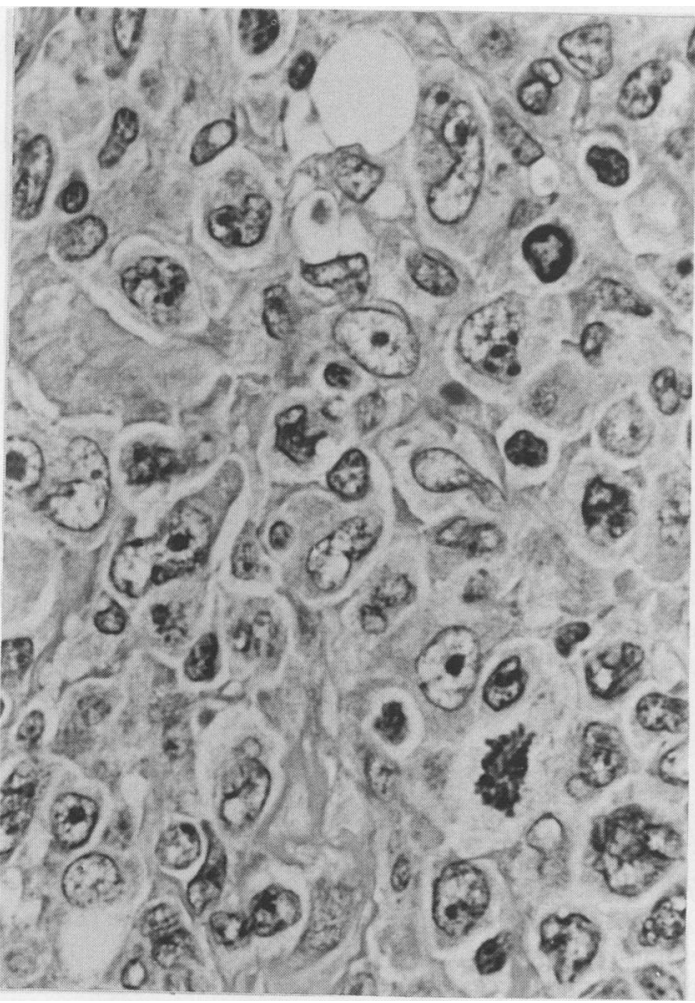

Fig 11 Pleomorphic large cell type. The tumour is mainly composed of large cells with large vesicular nuclei which are often highly irregular with complex, sometimes one sided ("jelly fish") invaginations. The cytoplasm is mostly pale. The tumour is intersected by a moderate amount of fibrous connective tissue. This case was HTLVI negative and of helper phenotype. (Haematoxylin and eosin.)

Lymphadenopathy-often generalised-hepatomegaly, and splenomegaly are common findings in the disease. Skin disease is common and takes the form of erythematous patches and papules or nodules, or both. Histologically the lesions resemble those of mycosis fungoides, often with epidermal infiltration and Pautrier's microabscesses.

Hypercalcaemia is quite often associated (up to $50 \%$ ) with this disease and may result in renal failure and coma. Due to considerable reduction in both humoral and cellular immunity, patients are very susceptible to various infectious organisms, hence overwhelming infections are a common cause of death.

As the name implies, this category is remarkable chiefly for the extreme pleomorphism of the neoplastic cells. This is often more noticeable in ATLL than it is in HTLV-1 negative cases. In typical cases there is considerable variation in size (anisocytosis), as well as variation in shape of the nuclei. The nuclei range from medium size (with a nuclear diameter of
5-9 $\mu \mathrm{m})$ to large $(10-12 \mu \mathrm{m})$ and many mitotic figures are present. In large cells the nuclei tend to be vesicular with a distinct nuclear membrane and two to five conspicuous nucleoli, whereas medium sized cells have a more condensed chromatin. The nuclei, especially of large cells, are often round to oval, but nuclei with one sided multiple invaginations (jelly fish or banana bunch appearance $)^{31}$ are found in all cases. The cytoplasm of the neoplastic cells is usually pale and grey with Giemsa staining in HTLV-1 negative tumours, but tends to be more basophilic (and sometimes intensely so) in ATLL. Giant cells are often found in tumours of this type. Two kinds of giant cell are recognised: in one the nuclei resemble those of Sternberg-Reed cells, the other shows noticeable nuclear convolution, a coarsely aggregated basophilic chromatin pattern, and two to three prominent nucleoli (fig 12). ${ }^{97}$ The cerebriform giant cells of the latter type are particularly characteristic of HTLV-1 positive tumours and are a fairly reliable indication of virus positivity.

The neoplastic cells are usually intermingled with fairly abundant histiocytes. Plasma cells are few, but eosinophils are sometimes plentiful. High endothelial venules may be conspicuous, but they are generally straight or only slightly curved and are not arborising.

Immunologically the tumours of ATLL (and other pleomorphic $T$ cell tumours) as a rule show the phenotype of peripheral T helper/inducer cells (CD3 positive, CD4 positive, CD1 negative, $C D 8$ negative) with concomitant expression of HLA-DR (Ia) and Tac antigens. These tumours are rarely of suppressor/cytotoxic type but a very few cases have been confirmed by viral genome studies (unpublished observations). A few tumours of ATLL, especially of the medium sized cell variant, have been shown to express simultaneously, on some, or even on most of their cells, CD4 and CD8 antigens, but the cells are negative for thymus cortex antigen (CD1). ${ }^{98}$

We have already reported ${ }^{37}$ that the virus positive lymphomas differ considerably from the negative cases in their expression of antibodies; virus positive cases are consistently CD7 negative, but have IL2 receptors. The prognosis in the pleomorphic medium sized and large cell $T$ lymphomas is generally extremely grave, but is worst in ATLL (median survival time 4.7 months). This may at least in part be explained by the much higher incidence of leukaemia and hypercalcaemia in this disease, both of which adversely affect the prognosis. Most cases of the pleomorphic type show a decreased serum immunoglobulin concentration; a few exhibit polyclonal or even monoclonal hypergammaglobulinaemia. It is a property of $\mathrm{T}$ cell lymphomas in general that the cellular immunity of the patients is considerably low- 


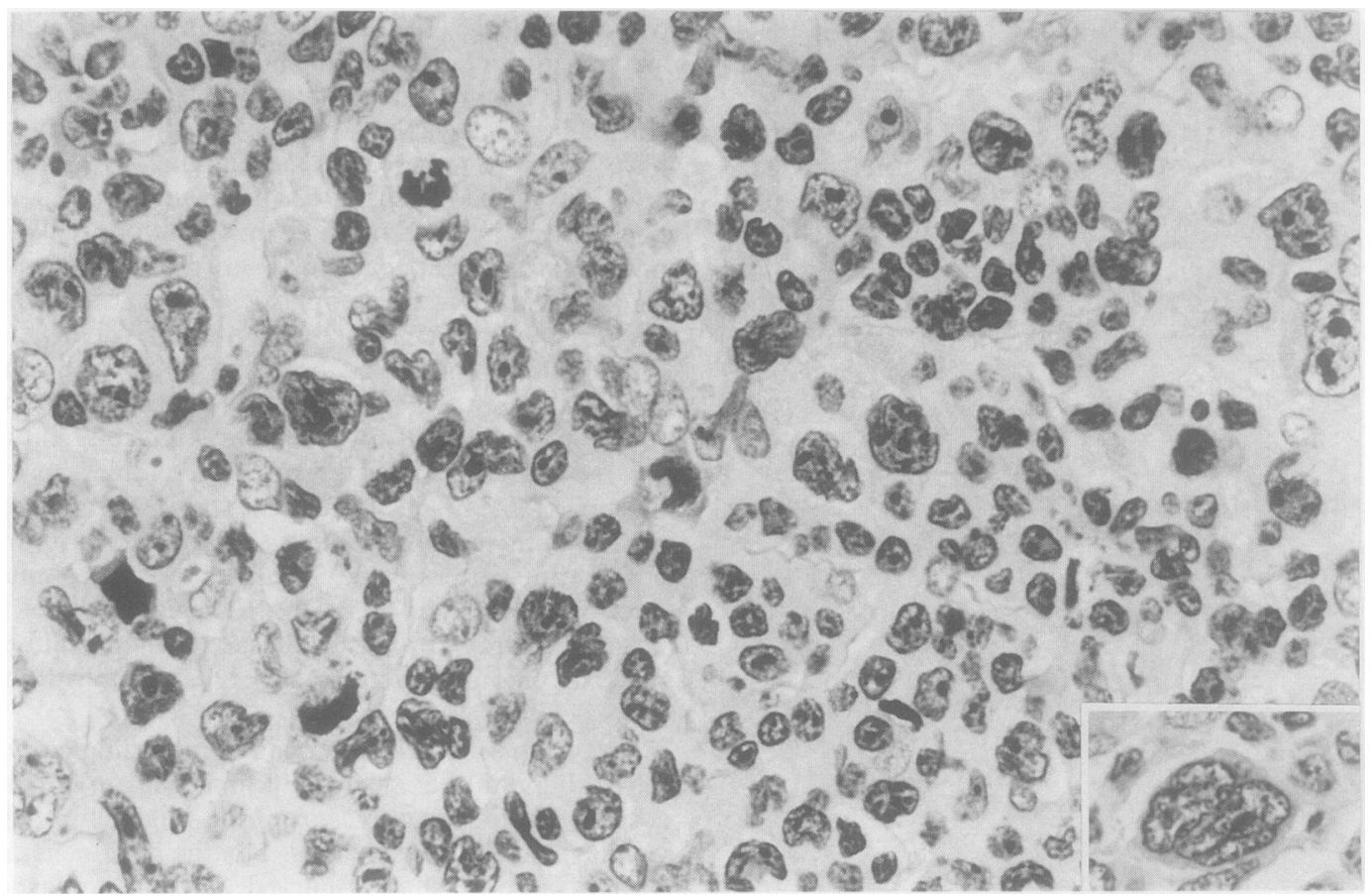

Fig 12 Pleomorphic type (adult I cell leukaemia/lymphoma). This is a typical appearance of the tumour seen in cases of HTLVI positive ATLL. The neoplastic cells are very variable in size, with some giant cells of both the types described in the text. Most of the nuclei show, regardless of their size, pronounced irregularity in shape. Cerebriform giant cell fairly specific for ATLL (insert). (Haematoxylin and eosin.)

ered, with an increased susceptibility to various kinds of viral, bacterial, and other infectious organisms, including opportunistic pathogens, but this property is especially pronounced in the HTLV-1 positive cases. Although classical ATLL has an extremely bad prognosis, there are chronic and smouldering types ${ }^{99}$ of ATLL which show fewer leukaemic cells in the peripheral blood and a prolonged clinical course. It has also been reported that a variable proportion (up to $40 \%$ ) of the inhabitants of the endemic areas are healthy carriers of the virus. ${ }^{100}$ These persons are seropositive for anti-ATLA and have polyclonally integrated viral genomes in their $\mathrm{T}$ cells. The virus is mainly transmitted from mother to child or from husband to wife. ${ }^{101-104}$ It has been estimated that one of every 900 male carriers and one of 2000 female carriers older than 40 develop ATLL each year. ${ }^{100}$

\section{(ii) IMMUNOBLASTIC (fig 13)}

This type of lymphoma is composed of fairly uniform large cells with large $(10-12 \mu \mathrm{m})$, round or oval nuclei, which lack pronounced pleomorphism and show vesicular chromatin and mostly one (to a few) prominent nucleoli. Some of the small nuclei may be irregular. Depending on the cytoplasmic staining, this lymphoma may be subdivided into two variants: (i) basophilic; and (ii) non-basophilic. The first variant is composed mainly of large cells with basophilic (pyroninophilic) cytoplasm, thus resembling the cells of B immunoblastic lymphomas. The second variant is composed mainly of large cells with either pale stained, fairly abundant cytoplasm, or a very abundant, water clear cytoplasm. In both variants eosinophils are sometimes seen, but other reactive elements such as plasma cells are rare. The high endothelial venules are usually indistinct. Giant cells are rarely seen in this type. HTLV-1 positivity is sometimes observed, predominantly in the basophilic variant. The basophilic variant has been of a helper/inducer phenotype (CD4 positive) in all cases investigated so far; occasional cases with nonbasophilic cytoplasm have been shown to be of a suppressor/cytotoxic phenotype (CD8 positive). A leukaemic manifestation is commonly seen in the ATLL cases, but otherwise it is rare in the T immunoblastic type.

(iii) LARGE CELL ANAPLASTIC TYPE

(K I- 1 -POSITIVE) (fig 15)

The existence of this entity within the category of peripheral $\mathrm{T}$ cell lymphomas was recognised using the monoclonal antibody $\mathrm{Ki}-1 .{ }^{105}$ This antibody was 


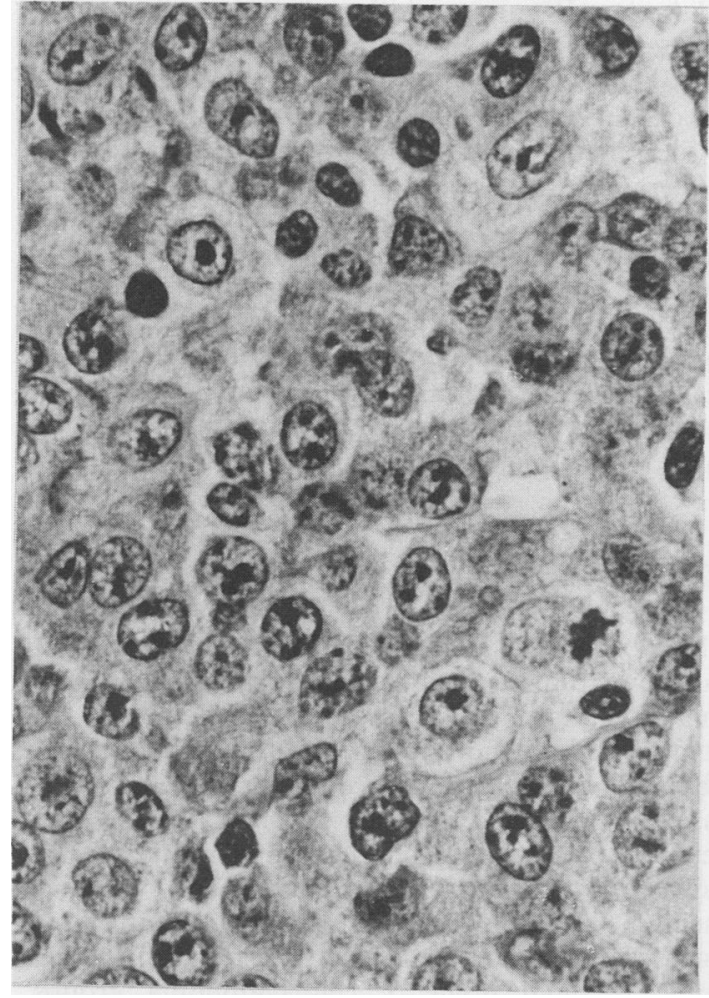

Fig 13 Immunoblastic type. The nuclei are uniformly large in size, round or oval in shape, and show one to a few prominent nucleoli. The cytoplasm is largely basophilic but occasionally pale. This case was HTLVI negative, and of suppressor phenotype. (Haematoxylin and eosin.)

recently assigned to $\mathrm{CD} 30$, based on the experimental data of Stein et al ${ }^{106}$ which showed that $\mathrm{Ki}-1$ antibody recognises an antigen present on activated $T$ and $B$ lymphocytes. The antibody reacts with the Sternberg-Reed cells and Hodgkin's cells of Hodgkin's disease, but positivity is also found on some lymphoma cells of non-Hodgkin's $T$ cell and less commonly, B cell lymphomas.

These tumours, in which only a proportion of the neoplastic cells express the $\mathrm{Ki}-1$ antigen, may be readily distinguished from the type of lymphoma described below in which every cell stains strongly with the Ki-1 antibody. Furthermore, the large cell anaplastic $T$ cell lymphoma has other clinical and morphological features which distinguish this as a separate entity; and neither the diagnosis nor the designation of the tumour should rely solely on the reactivity of the neoplastic cells with a single antibody.

The large cell anaplastic T cell lymphoma (so called " $\mathrm{Ki}-1$ lymphoma") is mainly composed of very large neoplastic cells with abundant moderately basophilic cytoplasm (grey in Giemsa staining). While the nuclei

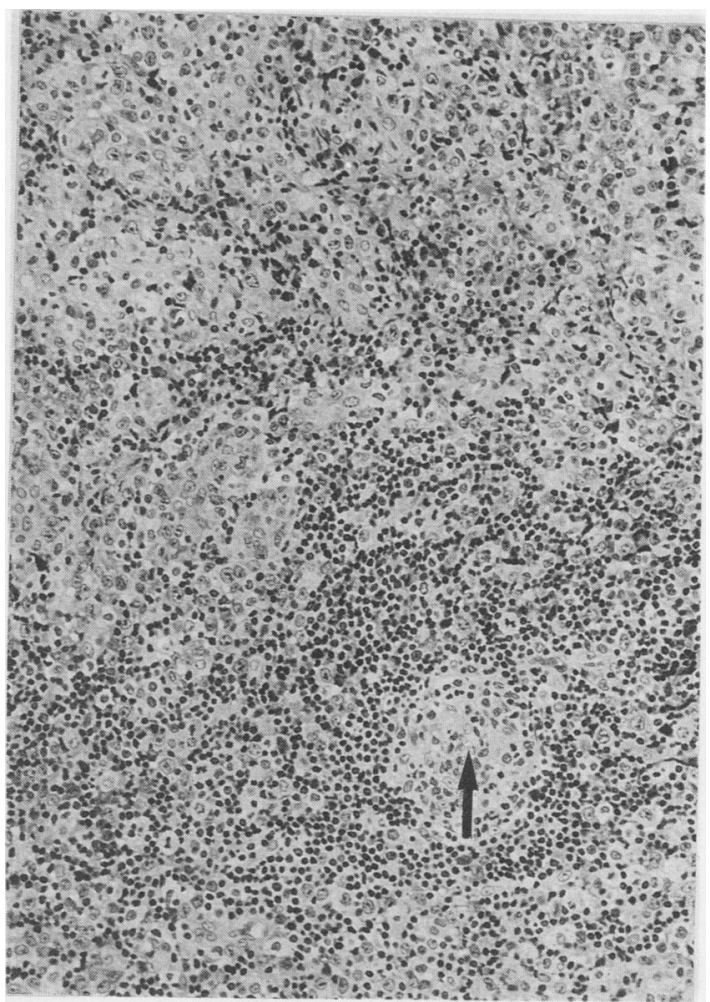

Fig 14 Large cell anaplastic type (Ki-1 lymphoma). The large neoplastic cells seem to form rather circumscribed nests of cohesive-looking cells, reminiscent of epithelial tumours. A spared but atrophic germinal centre is seen (arrow).

(Haematoxylin and eosin.)

vary in shape, they are usually only moderately irregular with some indentations.

The largest cells, with abundant often vacuolated cytoplasm, tend to have more irregularly shaped nuclei with peripherally condensed chromatin and sometimes a single prominent nucleolus. The cells of somewhat smaller size have more regular nuclei with pleomorphic, medium sized nucleoli and a moderate amount of basophilic cytoplasm. Giant cells are commonly seen and are sometimes quite numerous: their nuclei are multiple or multilobated and tend to be situated near the periphery of the cytoplasm surrounding a pale area (Golgi body?). There may also be cells more or less closely resembling SternbergReed cells.

The tendency of the neoplastic cells to form seemingly cohesive sheets has sometimes led to the misdiagnosis of anaplastic carcinoma or melanoma; and the common finding of discrete tumour nodules in a partially diseased node may corroborate a diagnosis of metastatic tumour. The infiltrate tends to show a $\mathrm{T}$ zone distribution with sparing of $\mathrm{B}$ follicles 


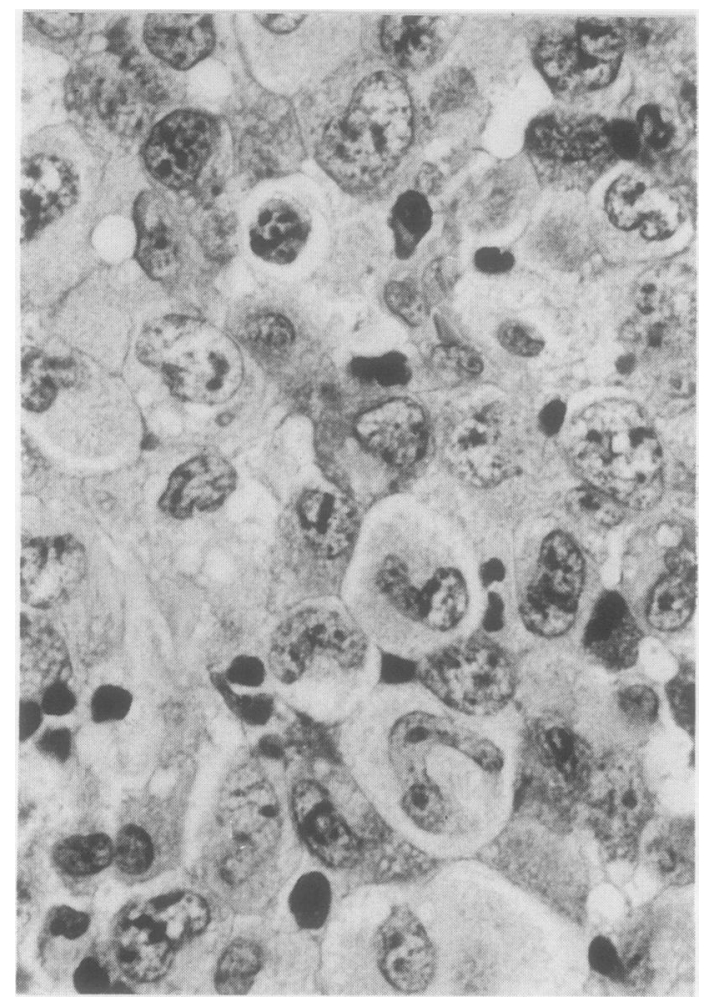

Fig 15 Large cell anaplastic type (Ki-1 lymphoma). A higher magnification shows the tumour to be composed of large cells with abundant pale cytoplasm. The cytoplasm is often condensed toward the nuclei by fixation, leaving an empty space at the margin. Many of the tumour cells show large, round to oval, vesicular nuclei with two to five nucleoli, while some show nuclei with irregular indentation. Giant sized cells may show horseshoe shaped nuclei partly encircling a central pale area. (Haematoxylin and eosin.)

and strong intrasinusoidal permeation. This permeation, together with the common accompaniment of large actively phagocytic macrophages has, at other times, raised the possibility of malignant histiocytosis. Foci of necrosis and fibrosis are often seen.

Although the large cell anaplastic $\mathrm{Ki}-1$ positive lymphomas of this type usually prove on immunophenotypic analysis to be $T$ cell in origin, a few tumours of identical morphology carry B cell or even, in rare instances, monocytic antigens. ${ }^{107}$ The antigenic profile of the T cell tumour is often incomplete, sometimes lacking CD3 or CD2, and lineage specific markers may be totally absent ("null type"). The lineage of these tumours can then be identified by gene rearrangement studies.

In addition to the strong expression of the $\mathrm{Ki}-1$ (activation) antigen by these tumours, most are positive also for both anti-Tac (I1-2 receptor) ${ }^{108}$ and
Suchi, Lennert, Tu, Kikuchi, Sato, Stansfeld, Feller HLA class II antigen. Although the neoplastic cells are negative for cytokeratin, they may express epithelial membrane antigen (EMA). About one third of the cases lack the leucocyte common antigen.

$T$ cell lymphomas of this type are seen more often in a younger age group ( $<20$ years) than other types of peripheral $\mathrm{T}$ cell lymphoma, and they also have a relatively better prognosis than other high grade $T$ cell lymphomas. $\mathrm{Ki}-1$ positive large cell anaplastic lymphomas of $\mathrm{T}$ type may be primary or secondarythat is, they may occur after low grade $T$ cell lymphomas as well as after Hodgkin's lymphomas. In the secondary type the prognosis is worse than in the primary type (unpublished observations).

\section{Rare and questionable types of $\mathbf{T}$ cell lymphoma}

This working classification of $\mathrm{T}$ cell lymphomas contains only tumour types of which we have seen more than five cases. These categories, however, do not comprise all the morphological variants that we have observed or those described in the literature. For instance, we found one case consisting of the same cells as LeL but without epithelioid cells. Likewise, we saw two lymphomas consisting of uniform basophilic medium sized cells somewhat similar to centroblasts. Such cases we include for the time being in the low grade or high grade $\mathrm{T}$ cell lymphoma groups respectively, in anticipation of further corroboration.

In the published reports we found descriptions of some rare or even questionable cases of $\mathrm{T}$ cell lymphoma. The most important being: hairy cell leukaemia of T type 109110 ; the large "multilobated" cell type $^{18}$; the erythrophagocytic T gamma lymphoma ${ }^{20}$; the lymphoma of plasmacytoid $\mathrm{T}$ cells ${ }^{111}$; the lymphohistiocytic lymphoma ${ }^{107}$; Liebow's lymphomatoid granulomatosis ${ }^{112}$; angiocentric $T$ cell lymphoma ${ }^{34}$; and $\mathrm{T}$ cell signet ring cell lymphoma. ${ }^{113}$

Saxon et al ${ }^{109}$ published a case of a T lymphocyte variant of hairy cell leukaemia (HCL), which had the typical morphology of hairy cells both on light and electron microscopy, tartrate resistant acid phosphatase positivity of the hairy cells, and massive splenomegaly. This case turned out to be the first observation of a HTLV-2 positive T cell lymphoma. ${ }^{110}$ Two leucopenic chronic $T$ cell leukaemias mimicking HCL were published by Sohn et al, ${ }^{14}$ showing either HTLV-1 or HTLV-2 positivity. Other reported examples of $\mathrm{HCL}$ of $\mathrm{T}$ type are not completely convincing. Tartrate resistant acid phosphatase positivity alone is not proof of $\mathrm{HCL}$ as this reaction is also found in T-CLL and Tprolymphocytic leukaemia.

The large "multilobated" cell type was described by Pinkus et $a^{18}$ as a proliferation of large histiocyte- 
like cells with prominent multilobated nuclei. The $T$ cell nature of the tumour cells has been confirmed by the capacity to form rosettes with sheep erythrocytes. On the other hand, some recent reports ${ }^{31115116}$ and our own experience provided increasing evidence that most lymphomas with this morphological feature are of $B$ cell origin and of centroblastic type.

Kadin $e t a^{20}$ described a $\mathrm{T}$ cell lymphoma occurring in two men both in their 4th decade which the authors called "erythrophagocytic $\mathrm{T}$ gamma lymphoma". The tumour cells looked like lymphocytes, but were slightly larger (up to twice the normal diameter) and often contained phagocytosed erythrocytes. Immunologically the cells proved to be peripheral T lymphocytes (TdT negative) and of the T gamma type (=T8 type), but they did not show azurophilic granules, and there were no leukaemic blood cells. Both lymphomas were resistant to polychemotherapy.

A lymphoma of plasmacytoid $\mathrm{T}$ cells was described by Müller-Hermelink et al, ${ }^{111}$ Prasthofer et al, ${ }^{117}$ and Beiske et al. ${ }^{118}$ In all three cases there was a monotonous proliferation of medium sized cells with a moderate amount of grey cytoplasm (with Giemsa staining) and round to oval nuclei containing small nucleoli. Cells with this morphology were described at first as lymphoblasts, ${ }^{119}$ but are now interpreted as plasmacytoid $\mathrm{T}$ cells, ${ }^{90}$ because they contain rather large amounts of rough endoplasmic reticulum, show T4 positivity, and lack B cell markers. All three reported lymphomas of this cell type were associated with or developed a myeloproliferative disorder: two had myelomonocytic leukaemia and one chronic myeloid leukaemia.

Lymphohistiocytic lymphoma was first presented as a new entity in a workshop of the European Lymphoma Club by Hamlin and Stansfeld in 1975 and later at the 24th Congress of the Japanese RES Society in 1984 by Lennert et al. ${ }^{107}$ The tumour is composed of $\mathrm{T}$ lymphocytes, $\mathrm{Ki}-1$ positive large blast cells, and numerous histiocytes which sometimes show eccentric round nuclei like those of plasma cells and occasionally, erythrophagocytosis. There are rare similar lesions which seem to be clinically benign (induced by virus?). One of the malignant variants showed trisomy 7 . Perhaps the malignant variant is identical with the lesion described by Jaffe et $a l^{120}$-"malignant lymphoma and erythrophagocytosis simulating malignant histiocytosis".

Under the heading of angiocentric immunoproliferative lesions, $\mathrm{Jaffe}^{34}$ includes, among other lesions, Liebow's lymphomatoid granulomatosis, ${ }^{112}$ as representing the same pathological process as midline granuloma, and so called angiocentric lymphoma. In both instances a predominant vessel involvement was described, but the question is whether the vessel lesions are indeed the central morphological feature. One of us (KL) had the opportunity to see many so called midline granulomas collected in Hong Kong and in Singapore. All cases belonged to the pleomorphic $\mathrm{T}$ cell lymphomas of our classification, comprising the small, medium sized, and large cell types. Vessel lesions were seen only in a small proportion of the cases. The findings were similar in our own small series of cases of "midline granuloma" which were, without exception, typical pleomorphic $T$ cell lymphomas. In one case of a malignant lymphoma of the stomach, however, we observed severe inflammatory and thrombotic vessel lesions, as well as destruction of small vessels by neoplastic $T$ cells. These were interpreted as $T$ immunoblasts. This case fulfils the criteria described by Jaffe for angiocentric lymphoma. ${ }^{34}$

Weiss $e a^{113}$ introduced the term "signet-ring cell lymphoma" for a diffuse large cell lymphoma in which many tumour cells contained cytoplasmic vacuoles imparting a signet ring configuration. In two described cases the tumour cells were not of B cell (follicular) origin but were derived from peripheral T cells.

\section{Unclassified lymphomas}

T cell lymphomas vary more in their cytological composition within a single subtype than B cell lymphomas. We are often confronted with unexpected variants which we cannot classify with certainty, but usually we can recognise the $T$ cell nature of the lymphoma (and should confirm it immunohistochemically). These cases can therefore be termed unclassified. In most cases, however, we can decide whether the tumour is of low or high grade malignancy: low grade lymphomas consist mainly of nonbasophilic cells ("-cytes") with the admixture of some basophilic cells ("-blasts"), whereas high grade lymphomas consist either of medium sized or large pleomorphic cells or only of blast cells. There are also lymphomas which we are unable even to decide whether they are of low or high grade type.

The unclassified $\mathrm{T}$ cell lymphomas can be classified in three categories: (i) unclassified $\mathbf{T}$ cell lymphoma, low grade; (ii) unclassified $\mathrm{T}$ cell lymphoma, high grade; (iii) unclassified $\mathrm{T}$ cell lymphoma, indeterminate.

EPITHELIOID CELLS IN T CELL LYMPHOMAS Epithelioid cells are often found in T cell lymphomas, usually forming small clusters. If these are associated with a predominant population of small lymphocytes with some medium sized and large cells (immunoblasts) the lesion may properly be called lymphoepithelioid lymphoma (LeL). 
There is, however, a similar lymphoma characterised by a large number of venules, eosinophils, and plasma cells, which essentially belong to the $T$ cell lymphoma of AILD type. In both instances the lymphocytes may have round nuclei or may be somewhat pleomorphic. If, however, the cytological pattern of another $\mathrm{T}$ cell lymphoma is present-pleomorphic or immunoblastic - this should not be called LeL, because the clinical pattern is different and is dictated by the type of proliferating $T$ cell, irrespective of the admixture of epithelioid cells.

There are good reasons to suppose that epithelioid cells are derived from monocytes via lymphokines produced by CD4 cells. It is understandable that the transformation of LeL into a high grade T cell lymphoma may lead to a reduction or even a disappearance of epithelioid cells, because of dedifferentiation of the tumour cells. Sometimes, however, very immature looking $\mathrm{T}$ cell lymphomas may be associated with many epithelioid cells, thus showing unexpected functional activity of the tumour cells.

\section{CLEAR CELLS IN T CELL LYMPHOMAS}

So called "clear cells" were first described by Suchi ${ }^{67}$ in lesions which would now be called AILD or $\operatorname{LgX}$. These very distinctive cells are a conspicuous feature in many peripheral $\mathrm{T}$ cell lymphomas, notably those of AILD and T zone type. They are far less often seen in the lymphoepithelioid and T immunoblastic lymphomas and are very rarely found in HTLV-1 positive $T$ cell lymphomas. The occurrence of similar cells in B cell lymphomas is rarer still, so their presence in a lymphoma is a useful indication of its $\mathrm{T}$ cell origin.

Clear cells are characterised by abundant cytoplasm, varying from pale to "water clear" in routine formalin fixed sections, and it is this feature which makes them stand out so sharply when viewed against a background of lymphocytes having little cytoplasm. Their nuclei are usually round but occasionally irregular and range from small to large in size. Some T cell lymphomas are composed almost entirely of clear cells, but they are most often seen in clusters or larger aggregates with a background of other cells. In the experience of one of the authors (TU) tumours with many clear cells are a common type in China, the nuclear size of the cells being a useful guide to the prognosis, which is best when the nuclei are small and worst when they are large.

The mechanism of formation of clear cells in $T$ cell lymphomas is still unknown. It is exceptional for the cell cytoplasm to stain positively for glycogen with periodic acid Schiff, and usually they are periodic acid Schiff negative. ${ }^{79}$ Clear cells are generally of helper phenotype (CD4 positive) but may be of a suppressor phenotype (CD8 positive) in a few cases. Clinical fea- tures specific to the presence of clear cells have not been identified.

As clear cells may be seen in almost any type of peripheral T cell lymphoma except ATLL we rejected the idea of making a separate "clear cell lymphoma" category, but instead we advise that the presence of clear cells should be noted in reporting on such tumours.

\section{Clinical aspects}

A rather comprehensive clinicopathological study of peripheral $\mathrm{T}$ cell lymphomas has been published by Greer $e a \mathrm{al}^{33}$ and a more recent report has come from Weis et al. ${ }^{121}$ The relevant clinical features and prognosis of our various types of peripheral $\mathrm{T}$ cell lymphoma have already been described here. Some of the fundamental data on the clinical aspect and the survival curves of major types observed in the laboratories of the authors (Aichi Cancer Center, and Kiel University) are summarised in table 2 and figs 16 and 17. There are a few noteworthy points on the data given in these tables and figures.

While most types of $\mathrm{T}$ cell lymphoma show varying degrees of male preponderance, the sex incidence in Lennert's lymphoma seems to be nearly equal, as observed by Noel et al. ${ }^{122}$ Peripheral T cell lymphomas are essentially diseases of adults and the elderly as shown in the table. An exception is seen in the large cell anaplastic type (Ki-1 lymphoma), which has been observed more often in children and young adults than in older age groups (unpublished observations). Patients with HTLV-1 positive ATLL have not predominantly been male and they are about 10 years younger on average than those with the virus negative counterpart. Leukaemia seems to be more often associated with virus positive than with virus negative

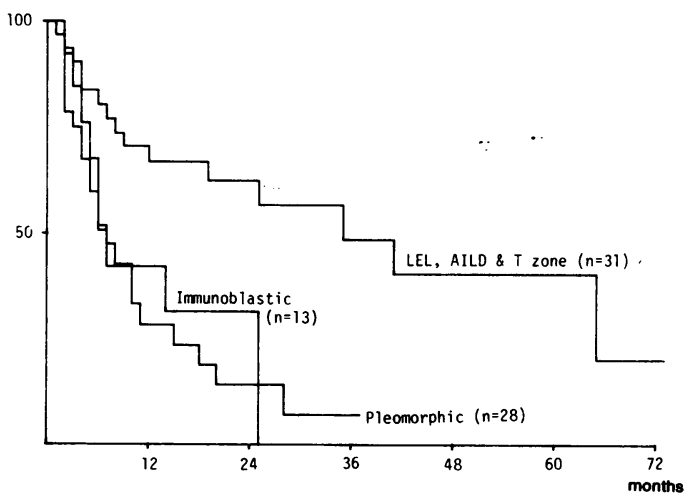

Fig 16 Actuarial survival (after Kaplan and Meier) of patients with pleomorphic type, (T) immunoblastic type and the three types (LeL, AILD, and T zone) of low grade category combined. Data from Aichi Cancer Centre. 
Table 2 Some basic clinical data of various types

\begin{tabular}{|c|c|c|c|c|c|c|c|}
\hline & No of cases & $\begin{array}{l}\text { Anti-ATLA* } \\
\text { in sera }\end{array}$ & Mean age & $\operatorname{Sex}(M: F)$ & Leukaemia & Hypercalcaemia & $\begin{array}{l}\text { Serum Ig } \\
\uparrow(\dagger) \downarrow\end{array}$ \\
\hline Lennert'sł & 109 & - & 61 & $55: 54$ & 0 & 0 & $16 / 6413 / 64$ \\
\hline Angioimmunoblastic $\uparrow$ & 17 & $1 / 11$ & 60 & $10: 7$ & 0 & 0 & $10(3) 2$ \\
\hline $\mathrm{T}$ zone 9 & 11 & $1 / 8$ & 57 & $8: 3$ & 1 & 0 & $8(3) 3$ \\
\hline Pleomorphic, small cell & 7 & - & 55 & $5: 2$ & $0 \&$ & 0 & $1 / 40 / 4$ \\
\hline $\begin{array}{l}\text { Pleomorphic, medium sized, } \\
\text { and large cell }\end{array}$ & 28 & $14 / 23$ & 53 & $14: 14$ & 14 & 9 & $6(2) \quad 17$ \\
\hline Immunoblastic & 10 & $2 / 9$ & 57 & $10: 0$ & 3 & 1 & $5(1) \quad 0$ \\
\hline Large anaplastic (Kil)‡ & 46 & - & 34 & $28: 18$ & 4 & 0 & 112 \\
\hline
\end{tabular}

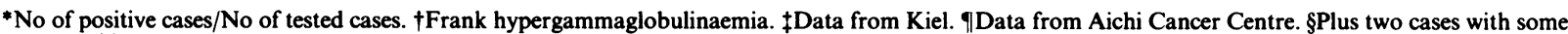
pleomorphic $\mathrm{T}$ cells in peripheral blood, but with normal leucocyte counts.

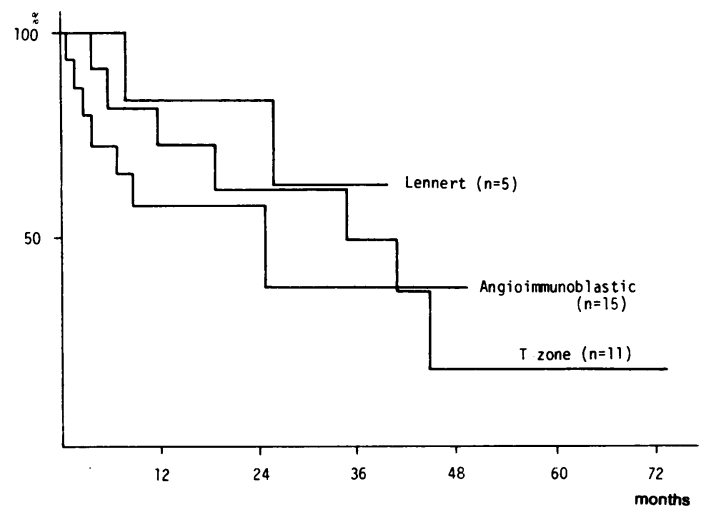

Fig 17 Actuarial survival (after Kaplan and Meier) of patients with lymphoepithelioid (Lennert's) lymphoma (LeL), angioimmunoblastic (AILD) type, and Tzone lymphoma. Data from Aichi Cancer Centre.

cases, and hypercalcaemia seems to be almost exclusively a property of virus positive cases.

The division of $\mathrm{T}$ cell lymphomas into the two major categories of low and high grade is based mainly on the cytological distinction of the principal component of the tumours and does not necessarily reflect the grade of aggressiveness in their clinical behaviour. A fairly good correlation can be seen, however, between our categorisation and the survival curves shown in figs 16 and 17. Survival time for the three low grade lymphomas-LeL, AILD-type, and T zone lymphoma-is longer than for the two high grade immunoblastic and pleomorphic (medium sized and large cell) lymphomas (fig 16). Fig 17 illustrates some differences in low grade types in a small series from the Aichi Cancer Center. Detailed data on a large series of all types of $\mathrm{T}$ cell lymphoma will be published soon.

\section{Discussion}

The recognition of a distinct morphological entity in all types of malignant lymphoma requires the histology of the neoplasm to remain fairly constant. Furthermore, for a fuller understanding of the entity and to fit it into a satisfactory scheme of classification, it is necessary to be able to identify the normal counterpart of the neoplastic cells, and preferably, to know also the normal differentiation or maturation sequence, or both, of the lymphoid cells in question. In the B cell system relatively distinct morphological pictures permit the formulation of a fairly complete and workable classification scheme for the B cell lymphomas. ${ }^{12312487}$

A major problem in the classification of $T$ cell lymphomas on morphological grounds is the extreme diversity in the histological appearances of these neoplasms. The admixture of different cell cohorts often makes it impossible to detect the neoplastic clone. Moreover, the neoplastic cell clone is often not a monomorphic cell population but may include cells at different stages of differentiation or activation, with different cytological appearances. In most instances it is hard to recognise the normal counterpart of the neoplastic cells. One may almost be driven to conclude that in classifying the $\mathrm{T}$ cell lymphomas, we require as many categories as the number of cases we see.

The introduction of monoclonal antibodies provided for the first time a method for confirming the $T$ cell nature of these lymphomas, but beyond this basic identification immunophenotyping has proved of very limited value in separating different categories of peripheral $\mathrm{T}$ cell lymphoma. While the cells in most peripheral $\mathrm{T}$ cell lymphomas have proved to be of helper/inducer subtype (CD4 positive), and only a few categories have shown a predominance of suppressor/cytotoxic T cells (CD8 positive), there are many inconsistencies in the expression of these markers. Some special characteristics, such as the state of activation of the cells, can be detected by the reactivity with different monoclonal antibodies (antiTac, ${ }^{108} \mathrm{Ki}-1^{105}$ ) though we do not yet fully understand the real meaning of these findings. 
In comparison with the B cell system, $\mathrm{T}$ cells seem to have a much wider range of functional capabilities, some of which are expressed in $\mathrm{T}$ cell neoplasms. Hypercalcaemia, often seen in ATLL, is apparently due to the production by the neoplastic $T$ cells of an osteoclast stimulating factor. The epithelioid cell component of Lennert's lymphoma is probably due to the production of MIF or related lymphokines. Patients with lymphomas of the AILD type have polytypic hypergammaglobulinaemia and can be shown to have high concentrations of immune complexes in their serum. ${ }^{125}$ This may be related to the deposition of periodic acid Schiff positive material on the basement membrane of high endothelial venules in these tumours. The occasional observation of follicular hyperplasia in $\mathrm{T}$ zone lymphoma may also be interpreted as a polytypic B cell proliferation induced by the neoplastic $T$ cells.

Finally, gene rearrangement studies have shown monoclonal $\mathrm{T}$ cell proliferation in some lesions that have hitherto been regarded as "atypical hyperplasia," a finding which has led to inclusion of this type of lesion in the T cell lymphomas of AILD type.

The classification we propose in this paper is based on cooperative studies at the workshop mentioned above $^{37}$ and on further studies during mutual visits to Germany, China, and Japan, supplemented by each author's experiences on the histological variations of $T$ cell lymphomas, correlated with immunological findings, DNA rearrangement studies, and clinical data.

Most of the entities in this classification were previously described by some of the present authors 232627303136 or by other investigators. ${ }^{282932}$ The terms originally used, however, have been more or less redefined.

In the primary subdivision we distinguished two main categories of $\mathrm{T}$ cell lymphoma/leukaemia. The distinction made on immunological criteria fits well with the morphology, the prethymic and thymic lymphomas all showing a lymphoblastic cytology, and the peripheral $\mathrm{T}$ cell lymphomas a great variety of cytological appearances.

We have divided the peripheral $\mathrm{T}$ cell lymphomas into two major categories of "-cytes" (low grade) and "-blasts" (high grade) according to the principle of the Kiel classification, although this distinction is often more difficult to make than it is with the B cell lymphomas.

If we are able to obtain a second or third biopsy specimen in the course of a low grade $T$ cell lymphoma, we realise how often a change in morphology occurs and how often a transformation into a high grade category occurs. Such secondary high grade $T$ cell lymphomas have long been known to occur in mycosis fungoides; they are found, however, in every type of low grade $\mathrm{T}$ cell lymphoma.

The lesions of the angioimmunoblastic type have not been regarded hitherto as malignant lymphomas but were thought to represent "abnormal immune reactions" or a "prelymphomatous" condition. Evidence accumulated in recent years, however, indicates that many of these lesions are neoplastic. Accordingly, they should be given a proper position in the scheme of peripheral $\mathrm{T}$ cell lymphomas. The lesions of the Lennert's and $T$ zone types have been occasionally misdiagnosed as other conditions, ranging from reactive conditions to various other types of malignant lymphoma.

In the high grade group we include not only the immunoblastic and anaplastic large cell types, but also the pleomorphic (medium sized and large cell) lymphomas, although tumours in the latter category are not necessarily recognisable as consisting predominantly of blast cells. Clinically these behave as high grade lymphomas, more especially the HTLV-1 positive cases. Tumours associated with HTLV-1 have not been confined solely to the pleomorphic, medium, and large cell types, but have also quite often shown the features of the immunoblastic type and even sometimes those of the small cell types. Further studies, using biomolecular methods, of the neoplastic cells for proviral DNA integration are required to clarify whether the retrovirus HTLVcan be a causative agent of those low grade $T$ celf lymphomas which now seem to be virus negative? Recently a monoclonal antibody reactive with HTLV-1 gene products has been produced. ${ }^{126}$ Such antibodies, used histochemically, could help to elucidate this problem.

Lastly, we think most if not all histological varieties of the very diverse peripheral $\mathrm{T}$ cell lymphomas can be accommodated in one or another category of this classification, which may therefore be used as a "working classification" for the time being, to facilitate the development of the ideal classification of the $\mathrm{T}$ cell lymphomas.

\section{References}

1 Uchiyama T, Yodoi J, Sagawa K, Takatsuki K, Uchino $\mathbf{H}$ Adult T-cell leukemia: clinical and hematologic features of 17 cases. Blood 1977;50:481-92.

2 Catovsky D, Greaves MF, Rose M, et al. Adult T-cell lymphoma-leukaemia in blacks from the West Indies. Lancet 1982;i:639-43.

3 Swerdlow SH, Habeshaw JA, Rohatiner AZS, Lister TA, Stansfeld AG. Caribbean T-cell lymphoma/leukemia. Cancer 1984;54:687-96.

4 Poiesz BJ, Ruscetti FW, Gazdar AF, Bunn PA, Minna JD, Gallo RC. Detection and isolation of type $C$ retrovirus particles from fresh and cultured lymphocytes of a patient with cutaneous T-cell lymphoma. Proc Natl Acad Sci USA 1980;77:7415-9. 
5 Hinuma Y, Nagata K, Hanaoka M, et al. Adult T-cell leukemia: antigen in an ATL cell line and detection of antibodies to the antigen in human sera. Proc Natl Acad Sci USA 1981;78:6476-80.

6 Hanaoka M, Takatsuki K, Shimoyama M. Adult T-cell leukemia and related diseases. GANN Monograph on Cancer Research No 28 Tokyo. Japan Scientific Societies Press, 1982.

7 The T- and B-cell malignancy study group. Statistical analysis of immunologic, clinical and histopathological data on lymphoid malignancies in Japan. Jpn J Clin Oncol 1981;11:15-38.

8 Shimoyama M. Symposium on adult T-cell leukemia-related diseases. Jpn J Clin Oncol 1983;13(Suppl 2):165-88.

9 Shimoyama M, Watanabe S. Symposium on T-cell malignancies. Jpn J Clin Oncol 1979;9(Suppl 1).

10 Jaffe ES, Blattner WA, Blayney DW, et al. The pathologic spectrum of adult T-cell leukaemia/lymphoma in the United States. Human T. cell leukemia/lymphoma virus-associated lymphoid malignancies. Am J Surg Pathol 1984;8:263-75.

11 Blattner WA, Blayney DW, Robert-Guroff M, et al. Epidemiology of human T-cell leukaemia/lymphoma virus. $J$ Infect Dis 1983;147:406-15.

12 Bunn PA, Schechter GP, Jaffe E, et al. Clinical course of retrovirus-associated adult T-cell lymphoma in the United States. N Engl J Med 1983;309:257-64.

13 Suchi T, Tajima K, Nanba K, et al. Some problems on the histo-pathological diagnosis of non-Hodgkin's malignant lymphoma. A proposal of a new type. Acta Pathol Jpn 1979;29:755-76.

14 Lennert K. Klassifikation und Morphologie der Non-HodgkinLymphome. In: Löffler $\mathrm{H}$, ed. Maligne Lymphome und monoklonale Gammopathien. Hämatologie und Bluttransfusion. Vol. 18. Munich: Lehmanns, 1976:145-66.

15 Lennert K, Mohri N. Malignant lymphoma, lymphocytic, Tzone type (T-zone lymphoma). In: Lennert K, ed. Malignant lymphomas other than Hodgkin's disease. Berlin: Springer Verlag, 1978:196-209.

16 Waldron JA, Leech JH, Glick A, Flexner JM, Collins RD. Malignant lymphoma of peripheral T-lymphocyte origin. Immunologic, pathologic, and clinical features in six patients. Cancer 1977;40:1604-17.

17 Lukes RJ, Parker JW, Taylor CR, Tindle BH, Cramer AD, Lincoln TL. Immunologic approach to non-Hodgkin lymphomas and related leukemias. Analysis of the results of multiparameter studies of 425 cases. Semin Hematol 1978;15:322-51

18 Pinkus GS, Said JW, Hargreaves H. Malignant lymphoma, Tcell type: a distinct morphologic variant with large multilobated nuclei, with a report of four cases. Am J Clin Pathol 1979;72:540-50.

19 Palutke M, Pabaczka P, Weise RW, et al. T-cell lymphomas of large cell type. A variety of malignant lymphomas: "histiocytic" and mixed lymphocytic-"histiocytic". Cancer 1980;46:87-101.

20 Kadin ME, Kamoun M, Lamberg J. Erythrophagocytic Tgamma lymphoma. A clinicopathologic entity resembling malignant histiocytosis. $N$ Engl J Med 1981;304:648-53.

21 Shimoyama M, Minato K, Saito H, et al. Immunoblastic lymphadenopathy (IBL)-like T-cell lymphoma. Jpn J Clin Oncol 1979;9(Suppl):347-56.

22 Watanabe $\mathrm{S}$, Shimosato $\mathrm{Y}$, Shimoyama $\mathrm{M}$, et al. Adult $\mathrm{T}$ cell lymphoma with hypergammaglobulinemia. Cancer 1980;46: 2472-83.

23 Kikuchi M, Mitsui T, Matsui N, et al. T-cell malignancies in adults: histopathological studies of lymph nodes in 111 patients. Jpn J Clin Oncol 1979;9(Suppl):407-22.

24 Kikuchi M, Mitsui T, Eimoto T, Toyooka R, Nishiuchi M. Biopsy of adult T cell leukemia. GANN Monograph on Cancer Research 1982;28:37-47.

25 Takatsuki K, Uchiyama T, Ueshima $Y$, et al. Adult $T$ cell leukemia: Proposal as a new disease and cytogenetic, phenotypic, and functional studies of leukemic cells. GANN Monograph on Cancer Research 1982;28:13-22.

26 Suchi T, Tajima K. Peripheral T-cell malignancy as a problem in lymphoma classification. Jpn J Clin Oncol 1979;9(Suppl): 443-50.

27 Suchi T. Malignant lymphomas in Japan. In: Levy E, ed. Advances in pathology. Vol 2. Oxford: Pergamon Press, 1982:71-5.

28 Watanabe S, Shimosato Y, Shimoyama M. Lymphoma and leukemia of T-lymphocytes. Pathol Annu 1981;16(part 2):115-203.

29 Watanabe S. Pathology of peripheral T-cell lymphomas and leukemias. Hematol Oncol 1986;4:45-58.

30 Stein H, Tolksdorf G, Lennert K. T-cell lymphomas. A cell origin related classification on the bases of cytologic, immunologic, and enzyme cytochemical criteria. Pathol Res Pract 1981;171:197-215.

31 Lennert K, Stein H, Feller AC, Gerdes J. Morphology, cytochemistry, and immunohistology of $T$ cell lymphomas. In: Vitetta ES, ed. B and T cell tumors. UCLA symposia on molecular and cellular biology. Vol XXIV. New York: Academic Press, 1982:9-28.

32 Wright DH, Isaacson PG. Pathology of the lymphoreticular system. London: Chapman \& Hall, 1983:203-29.

33 Greer JP, York JC, Cousar JB, et al. Peripheral T-cell lymphoma: A clinicopathologic study of 42 cases. J Clin Oncol 1984;2:788-98.

34 Jaffe $E$. The pathologic and clinical spectrum of post-thymic $T$ cell malignancies. Cancer Invest 1984;2:413-26.

$35 \mathrm{Xu} \mathrm{LZ,} \mathrm{Tu} \mathrm{LY,} \mathrm{Liu} \mathrm{YF,} \mathrm{et} \mathrm{al.} \mathrm{Phenotypic} \mathrm{expression} \mathrm{of} \mathrm{non-}$ Hodgkin's lymphomas in China. JNCI 1984;73:635-8.

36 Stansfeld AG. Peripheral T-cell lymphomas. In: Stansfeld AG, ed. Lymph node biopsy interpretation. Edinburgh: Churchill Livingstone, 1985:300-29.

37 Lennert K, Kikuchi M, Sato E, et al. HTLV-positive and -negative T-cell lymphomas. Morphological and immunohistochemical differences between European and HTLVpositive Japanese $T$-cell lymphomas. Int $J$ Cancer 1985;35:65-72.

38 Bernard A, Boumsell L, Reinherz B, et al. Cell surface characterization of malignant $\mathrm{T}$ cells from lymphoblastic lymphoma using monoclonal antibodies: evidence for phenotypic differences between malignant $T$ cells from patients with acute lympoblastic leukemia and lymphoblastic lymphoma. Blood 1981;57:1105-10.

39 Greaves MF. Analysis of the clinical and biological significances of lymphoid phenotypes in acute leukemia. Cancer Res 1981;41:4752-66.

40 Feller AC, Parwaresch MR, Stein H, Ziegler A, Herbst H, Lennert K. Immunophenotyping of T-lymphoblastic lymphoma/leukemia: correlation with normal T-cell maturation. Leuk Res 1986;10:1025-31.

41 Hui PK, Feller AC, Pileri S, Gobbi M, Lennert K. New aggressive variant of suppressor/cytotoxic T-CLL. Am J Clin Pathol 1987;87:55-9.

42 Hanaoka M. Adult T-cell leukemia and Sézary's syndrome. LeuLeukemia Reviews International 1984;2:17-44.

43 Matutes E, Garcia Talavera J, O'Brien M, Catovsky D. The morphological spectrum of T-prolymphocytic leukaemia. $\mathrm{Br}$ J Haematol 1986;64:111-24.

44 Catovsky D, Varadi S, Rose M, et al. The spectrum of chronic T-cell leukaemias (Abst III:11). International Society of Haematology, European and African Division Fifth Meeting 1979.

45 Costello C, Catovsky D, O'Brien M, Morilla R, Varadi S. Chronic T-cell leukemias. I. Morphology, cytochemistry and ultrastructure. Leuk Res 1980;4:463-76.

46 Catovsky D, Wechsler A, Matutes E, et al. The membrane phenotype of T-prolymphocytic leukaemia. Scand J Haematol 1982;29:398-403. 
47 Lutzner M, Edelson R, Schein P, Green I, Kirkpatrick C, Ahmed A. Cutaneous T-cell lymphomas: the Sézary's syndrome, mycosis fungoides, and related disorders. Ann Intern Med 1975;83:534-52.

48 Broder S, Bunn PA Jr. Cutaneous T-cell lymphomas. Semin Oncol 1980;7:310-31.

49 Lutzner M, Hobbs JW, Horvath P. Ultrastructure of abnormal cells in Sézary's syndrome, mycosis fungoides, and parapsoriasis en plaque. Arch Dermatol 1971;103:375-86.

50 Lutzner MA, Jordan HW. The ultrastructure of an abnormal cell in Sézary's syndrome. Blood 1968;31:719-26.

51 Kaiserling E. Mycosis fungoides. In: Lennert K, ed. Malignant lymphomas other than Hodgkin's disease. Handbuch der speziellen pathologischen Anatomie und Histologie. Vol I/3B. Berlin: Springer-Verlag 1978:486-90.

52 Lennert $\mathrm{K}$. Zur histologischen Diagnose der Lymphogranulomatose. Frankfurt: Habil-Schrift, 1952.

53 Lennert K, Mestdagh J. Lymphogranulomatosen mit konstant hohem Epitheloidzellgehalt. Virchows Arch (Pathol Anat) 1968;344:1-20.

54 Lennert K, Mohri N, Stein H, Kaiserling E. The histopathology of malignant lymphoma. Br J Haematol 1975;31(suppl): 193-203.

55 Palutke M, Varadachari C, Weise RW, Husain M, Tabaczka P. Lennert's lymphoma, a T-cell neoplasm. Am J Clin Pathol 1978;69:643-5.

56 Han T, Barcos M, Yoon JM, Rakowski I, Minowada J. Malignant lymphoma with a high content of epithelioid histiocytes: Report of a T-cell variant of so-called Lennert lymphomas and review of the literature. Med Pediatr Oncol 1980;8:227.

57 De Waele M, Van Belle S, Gepts W, Thielemans C, Schallier D, Van Camp B. A Lennert lymphoma with a helper-T-cell phenotype. N Engl J Med 1981;305:831-2.

58 Bogomoletz WV, Bernard J, Capron F, Diebold J. T-cell origin of Lennert's lymphoma. Immunohistochemical and immunologic study of one case. Arch Pathol Lab Med 1983;107:586-8.

59 Gerdes J, Lemke H, Baisch H, Wacker HH, Schwab U, Stein H Cell cycle analysis of a cell proliferation-associated human nuclear antigen defined by the monoclonal antibody Ki67. $J$ Immunol 1984;133:1710-5.

60 Lennert K, Feller AC. Morphology and immunohistology of T cell lymphomas. In: Quaglino D, Hayhoe FGJ, eds. The cytobiology of leukaemias and lymphomas. New York: Raven Press, 1985:81-90.

61 Feller AC, Griesser GH, Mak TW, Lennert K. Lymphoepithelioid lymphoma (Lennert's lymphoma) is a monoclonal proliferation of helper/inducer T cells. Blood 1986;68:663-7.

62 Gödde-Salz E, Feller AC, Lennert K. Cytogenetic and immunohistochemical analysis of lymphoepithelioid cell lymphoma (Lennert's lymphoma): further substantiation of its T-cell nature. Leuk Res 1986;10:313-23.

63 O'Connor NTJ, Feller AC, Wainscoat JS, et al. T-cell origin of Lennert's lymphoma. Br J Haematol 1986;64:521-8.

64 Dorfman RF, Warnke R. Lymphadenopathy simulating the malignant lymphomas. Hum Pathol 1974;5:519-50.

65 Lukes RJ, Tindle BH. "Immunoblastic lymphadenopathy", a hyperimmune entity resembling Hodgkin's disease. $N$ Engl J Med 1975;292:1-8.

66 Kim H, Nathwani BN, Rappaport H. So-called "Lennert's lymphoma". Is it a clinicopathologic entity? Cancer 1980;45:1379-99.

67 Suchi T. Atypical lymph node hyperplasia with fatal outcome. A report on the histopathological, immunological and clinical investigations of the cases. Recent Advances in RES Research 1974;14:13-34.

68 Lennert K. Pathologisch-histologische Klassifizierung der malignen Lymphome. In: Stacher A, ed. Leukämien und maligne Lymphome. Berlin: Urban \& Schwarzenberg, 1973:181-94.
69 Frizzera G, Moran EM, Rappaport H. Angioimmunoblastic lymphadenopathy with dysproteinaemia. Lancet 1974; 1070-3.

70 Nathwani BN, Rappaport H, Moran EM, Pangalis GA, Kim H. Malignant lymphoma arising in angio-immunoblastic lymphadenopathy. Cancer 1978;41:578-606.

71 Nathwani BN, Rappaport H, Pangalis G, Moran EM, Kim H. Immunoblastic lymphoma arising in angioimmunoblastic lymphadenopathy. In: Van den Tweel JG, Taylor CR, Bosman FT, eds. Malignant lymphoproliferative diseases. The Hague: Leiden University Press, 1980:273-9.

72 Kaneko Y, Larson RA, Variakojis D, Haren JM, Rowley JD Nonrandom chromosome abnormalities in angioimmunoblastic lymphadenopathy. Blood 1982;60:877-87.

73 Gödde-Salz E, Feller AC, Lennert K. Chromosomal abnormalities in lymphogranulomatosis $\mathbf{X}(\mathbf{L g r X})$ /angioimmunoblastic lymphadenopathy (AILD). Leuk Res 1987;11:181-90.

74 Fujita K, Fukuhara S, Nasu K, et al. Recurrent chromosome abnormalities in adult T-cell lymphomas of peripheral T-cel origin. Int J Cancer 1986;37:517-24.

75 Griesser GH, Feller AC, Lennert K, et al. The structure of the T cell gamma chain gene in lymphoproliferative disorders and lymphoma cell lines. Blood 1986;68:592-4.

76 Weiss LM, Strickler JG, Dorfman RF, Horning SJ, Warnke RA, Sklar J. Clonal T-cell populations in angioimmunoblastic lymphadenopathy and angioimmunoblastic lymphadenopathy-like lymphoma. Am J Pathol 1986; 122:392-7.

77 Suzuki H, Namikawa R, Ueda R, et al. Clonal T cell populations in angioimmunoblastic lymphadenopathy and related lesions. Japanese Journal of Cancer Research (In press).

78 Lennert K, Knecht H, Burkert M. Vorstadien maligner Lymphome. Verh Dtsch Ges Pathol 1979;63:170-96.

$79 \mathrm{Knecht} \mathrm{H}$, Lennert $\mathrm{K}$. Ultrastructural findings in lymphogranulomatosis X. [Angio-]immunoblastic lymphadenopathy Virchows Arch (Cell Pathol) 1981;37:29-47.

80 Lennert K, Feller AC, Gödde-Salz E. Morphologie, Immunohistochemie und Genetik peripherer T-Zellen-Lymphome. Onkologie 1986;9:97-107.

81 Namikawa $R$, Suchi $T$, Ueda $R$, et al. Phenotyping of proliferating lymphocytes in angioimmunoblastic lymphadenopathy and related lesions by double immunoenzymatic staining technique. Am J Pathol 1987: 279-87.

82 Griesser H, Feller AC, Lennert K, Minden M, Mak TW. Rearrangement of the $\beta$ chain of the $T$ cell antigen receptor and immunoglobulin genes in lymphoproliferative disorders J Clin Invest 1986;78:1179-84.

83 Frizzera G, Moran EM, Rappaport H. Angio-immunoblastic lymphadenopathy. Diagnosis and clinical course. Am J Med 1975;58:803-18.

84 Radaszkiewicz $T$, Lennert $K$. Lymphogranulomatosis $X$. Klinisches Bild, Therapie und Prognose. Deutsch Med Wochenschr 1975;100:1157-63.

85 Knecht H, Lennert K. Vorgeschichte und klinisches Bild der Lymphogranulomatosis $\mathbf{X}$ (einschließlich [angio] immunoblastischer Lymphadenopathie). Schweiz Med Wochenschr 1981;111:1108-21.

86 Knecht H, Lennert K. Verlauf, Therapie und maligne Transformation der Lymphogranulomatosis $\mathbf{X}$ (einschließlich [angio] immunoblastischer Lymphadenpathie). Schweiz Med Wochenschr 1981;111:1122-30.

87 Lennert K, Mohri N, Stein H, Kaiserling E, Müller-Hermelink HK. Malignant lymphomas other than Hodgkin's disease. Histology-Cytology-Ultrastructure-Immunology. Handbuch der speziellen pathologischen Anatomie und Histologie. Bd.I/3B. Berlin: Springer Verlag, 1978.

88 Kittas C, Hansmann ML, Borisch B, Feller AC, Lennert K. The blood microvasculature in T-cell lymphomas. A morphological, ultrastructural and immunohistochemical study. Vir chows Arch (Pathol Anat) 1985;405:439-52. 
89 Lennert K, Kaiserling E, Müller-Hermelink HK. T-associated plasma cells. Lancet 1975 ;i:1031-2.

90 Vollenweider R, Lennert K. Plasmacytoid T-cell clusters in nonspecific lymphadenitis. Virchows Arch (Cell Pathol) $1983 ; 44: 1-14$.

91 Suchi T, Tajima K. Histopathology of early lesions of peripheral T-cell lymphomas. Proceedings 13th International Cancer Congress, Seattle, Washington, USA, 1982:350.

92 Helbron D, Brittinger G, Lennert K. T-Zonen-Lymphom. Klinisches Bild, Therapie und Prognose. Blut 1979;39:117-31.

93 Yoshida M, Miyoshi I, Hinuma Y. Isolation and characterization of retrovirus (ATLV) and its association with adult T cell leukaemia. GANN Monograph on Cancer Research 1982;28:229-37.

94 Kadin ME, Kamoun $M$. Nonendemic adult T-cell leukemia/lymphoma. Hum Pathol 1982;13:691-3.

95 The T- and B-Cell Malignancy Study Group. Statistical analysis of clinico-pathological, virological and epidemilogical data on lymphoid malignancies with special reference to adult T-cell leukemia/lymphoma. A report of the second nationwide study of Japan. Jpn J Clin Oncol 1985;15:517-35.

96 Hattori T, Uchiyama T, Toibana T, Takatsuki K, Uchino H. Surfacephenotype of Japanese adult T-cell leukemia cells characterized by monoclonal antibodies. Blood 1981; 58:644-7.

97 Kikuchi M, Mitsui T, Takeshita M, Okamura H, Naitoh H, Eimoto T. Virus associated adult T-cell leukemia (ATL) in Japan: Its clinical, histological, and immunological studies. Hematol Oncol 1986;4:67-81.

98 Shamoto M, Kito K, Akatsuka H, Suchi T. Immunoelectron microscopic studies on peripheral $\mathrm{T}$-cell lymphomas using monoclonal antibodies. Virchows Arch (Cell Pathol) 1984;47:281-90.

99 Yamaguchi K, Nishimura H, Kawano F, et al. A proposal for smoldering adult T-cell leukemia. Diversity in clinical pictures of adult T-cell leukemia. Jpn J Clin Oncol 1983;13(suppl 2):189-200.

100 Tajima K, Kuroishi T. Estimation of incidence rate of ATL among ATLV-carriers in Kyushu, Japan. Jpn J Clin Oncol 1985;15:423-30.

101 Tajima K, Tominaga S, Suchi T, et al. Epidemiological analysis of the distribution of antibody to adult T-cell leukemia virusassociated antigen: possible horizontal transmission of adult T-cell leukemia virus. Jpn J Cancer Research GANN 1982;73:893-901.

102 Kinoshita K, Hino S, Amagasaki T, et al. Demonstration of adult T-cell leukemia virus antigen in milk from three seropositive mothers. Jpn $J$ Cancer Research GANN 194;75:103-5.

103 Komuro A, Hayashi M, Füi H, Miyahara S, Hivayama M. Vertical transmission of adult T-eenl kevilemia vinus. Lancet 1983;i:240.

104 Nakano S, Ando Y, Ichijo M, et al. Search for possible routes of vertical and horizontal transmission of adult T-cell leukemia virus. Jpn J Cancer Research GANN 1984;75:1044-5.

105 Schwab U, Stein H, Gerdes J, et al. Production of monoclonal antibody specific for Hodgkin and Sternberg-Reed cells of Hodgkin's disease and a subset of normal lymphoid cells. Nature 1982;299:65-7.

106 Stein H, Mason DY, Gerdes J. The expression of the Hodgkin's disease associated antigen $\mathrm{Kil}$ in reactive and neoplastic lymphoid tissue: evidence that Reed-Sternberg cells and histiocytic malignancies are derived from activated lymphoid cells. Blood 1985;66:848-58.

107 Lennert K, Feller AC, Radzun HJ. Malignant histiocytosis/histiocytic sarcoma and related neoplasms. Recent Advances in RES Research 1984;24:1-16.

108 Uchiyama T, Broder S, Waldmann TA. A monoclonal antibody (anti-Tac) reactive with activated and functionally mature human T cells. I. Production of anti-Tac monoclonal anti- body and distribution of Tac $(+)$ cells. $J$ Immunol 1981;126:1392-7.

109 Saxon A, Stevens RH, Quan SG, Golde DW. Immunologic characterization of hairy cell leukemias in continuous culture. $J$ Immunol 1978;120:777-82.

110 Kalyanaraman VS, Sarngadharan MG, Miyoshi I, Blayney D, Golde D, Gallo RC. A new subtype of human T-cell leukemia virus (HTLV-II) associated with a T-cell variant of hairy cell leukemia. Science 1982;218:571-3.

111 Müller-Hermelink HK, Stein H, Steinmann G, Lennert K. Malignant lymphoma of plasmacytoid T-cells. Morphologic and immunologic studies characterizing a special type of Tcell. Am J Surg Pathol 1983;7:849-62.

112 Liebow AA, Carrington CB, Friedman PJ. Lymphomatoid granulomatosis. Hum Pathol 1972;3:448-57.

113 Weiss LM, Wood GS, Dorfman FR. T-cell signet-ring cell lymphoma. A histologic, ultrastructural, and immunohistochemical study of two cases. Am J Surg Pathol 1985;9:273-80.

114 Sohn CC, Blayney DW, Misset JL, et al. Leukopenic chronic T cell leukemia mimicking hairy cell leukemia: association with human retroviruses. Blood 1986;67:949-56.

115 Pileri S, Brandi G, Rivano MT, Govoni E, Martinelli G. Report of a case of non-Hodgkin's lymphoma of large multilobated cell type with B-cell origin. Tumori 1982;68:543-8.

116 Van der Putte SCJ, Schuurman HJ, Rademakers LHPM, Kluin P, Van Unnik JAM. Malignant lymphoma of follicle centre cells with marked nuclear lobation. Virchows Arch (Cell Pathol) 1984;46:93-107.

117 Prasthofer EF, Prchal JT, Grizzle WE, Grossi CE. Plasmacytoid T-cell lymphoma associated with chronic myeloproliferative disorders. Am J Surg Pathol 1985;9:380-7.

118 Beiske K, Langholm R, Godal T, Marton PF. T-zone lymphoma with predominance of "plasmacytoid T cells" associated with myelomonocytic leukemia - a distinct clinicopathological entity. J Pathol 1987;150:247-55.

119 Lennert K. Lymphknoten. Diagnostik in Schnitt und Ausstrich. Bandteil A: Cytologie und Lymphadenitis. Handbuch der speziellen pathologischen Anatomie und Histologie. Band I/3A. Berlin: Springer Verlag, 1961.

120 Jaffe ES, Costa J, Fauci AS, Cossman J, Tsokos M. Malignant lymphoma and erythrophagocytosis simulating malignant histiocytosis. Am J Med 1983;75:741-9.

121 Weis JW, Winter MW, Phyliky RL, Banks PM. Peripheral Tcell lymphomas: Histologic, immunohistologic, and clinical characterization. Mayo Clin Proc 1986;61:411-26.

122 Noel H, Helbron D, Lennert K. Die epitheloidzellige Lymphogranulomatose (sogenanntes "Lennert's Lymphoma"). In: Stacher A, Höcker P, eds. Lymphknotentumoren. Munich: Urban \& Schwarzenberg, 1979:40-5.

123 Gerard-Marchant R, Hamlin I, Lennert K, Rilke F, Stansfeld AG, van Unnik JAM. Classification of non-Hodgkin's lymphomas. Lancet 1974;ii:406-8.

124 Lukes RJ, Collins RD. New approaches to the classification of the lymphomata. Br J Cancer 1975;31(suppl II):1-28.

125 Euler HH, Kern P, Löffler H, Dietrich M. Precipitable immune complexes in healthy homosexual men, acquired immune deficiency syndrome and the related lymphadenopathy syndrome. Clin Exp Immunol 1985;59:267-75.

126 Watanabe S, Sato Y, Shima H, Shimotohno K, Miwa M. Monoclonal antibody NCC-px-1G reactive with gene products coded from $X$ regions of human T-cell leukemia virus. Japanese Journal of Cancer Research 1986;77:338-41.

Requests for reprints to: $\operatorname{Dr} \mathrm{K}$ Lennert, Institute of Pathology, Christian-Albrecht University, Hospitalstrasae 42, 2300 Kiel 1, West Germany. 